\title{
Discovery of an additional piece of the large gymnophthalmid puzzle: a new genus and species of stream spiny lizard (Squamata: Gymnophthalmidae: Cercosaurinae) from the western Guiana Shield in Venezuela
}

\author{
FERNANDO J.M. ROJAS-RUNJAIC ${ }^{1 *}$, CÉSAR L. BARRIO-AMORÓS ${ }^{2}$, J. CELSA SEÑARIS ${ }^{3,4}$, \\ IGNACIO DE LA RIVA ${ }^{5} \&$ SANTIAGO CASTROVIEJO-FISHER ${ }^{4,6}$ \\ ${ }^{1}$ Museo de Historia Natural La Salle, Fundación La Salle de Ciencias Naturales, Caracas 1050, Distrito Capital, Venezuela \\ ${ }^{2}$ Doc Frog Expeditions/CRWild, 60504, Bahía Ballena, Uvita, Costa Rica

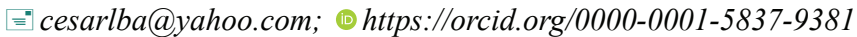 \\ ${ }^{3}$ PROVITA, calle La Joya con Av. Libertador, Unidad Técnica del Este, piso 10, oficina 29-30, Caracas 1060, Miranda, Venezuela \\ ="celsisenaris@gmail.com; ○ https://orcid.org/0000-0001-8673-7385 \\ ${ }^{4}$ Laboratório de Sistemática de Vertebrados, Pontifícia Universidade Católica do Rio Grande do Sul (PUCRS), Av. Ipiranga 6681, \\ Porto Alegre, RS 90619-900, Brazil \\ ${ }^{5}$ Museo Nacional de Ciencias Naturales-CSIC, C/ José Gutiérrez Abascal 2, 28006 Madrid, Spain \\ ”iriva@mncn.csic.es; ○ https://orcid.org/0000-0001-5064-4507 \\ ${ }^{6}$ Department of Herpetology, American Museum of Natural History, 200 Central Park West, New York, NY 10024-5102, USA \\ "'castroviejo.fisher@gmail.com; (1) https://orcid.org/0000-0002-1048-2168

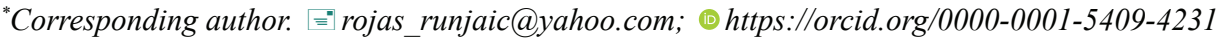

\begin{abstract}
Gymnophthalmids are a highly diverse group of Neotropical lizards and its species richness is still in process of discovery. The incorporation of molecular evidence and a noticeable increase in taxon and geographic sampling in systematic studies has led to the description of numerous new genera and species of gymnophthalmids (particularly in Cercosaurinae) in recent years. Herein we describe a new genus and species of cercosaurine lizard with crocodile-like morphology, from the Venezuelan Guiana Shield on the basis of molecular phylogenetic and morphological evidence. Kataphraktosaurus gen. nov. can be readily distinguished from all other genera of Cercosaurinae by a unique combination of morphological characters that includes heterogeneous dorsal scalation with enlarged and strongly keeled scales forming two paravertebral rows, ventral and subcaudal scales imbricated and strongly keeled, large and symmetrical cephalic scales, absence of postmental scale, palpebral disc translucent and divided, tail slightly compressed, all digits clawed, and only six femoral pores (three at each hindlimb) inserted in a clump of small scales. This genus is described as monotypic and only contains Kataphraktosaurus ungerhamiltoni sp. nov., which is known from one specimen and diagnosed by the same set of aforementioned characters. The secretive habits of this species and the remoteness of the locality may explain its singleton situation. Following the International Union for Conservation of Nature's criteria, we categorized the new species as Data Deficient.
\end{abstract}

Key words: Amazonia, biodiversity, Neotropics, Orinoco basin, phylogeny, reptile, systematics, taxonomy

\section{Resumen}

Gymnophthalmidae es un grupo de lagartos neotropicales muy diverso y su riqueza de especies aún está en proceso de descubrimiento. La incorporación de evidencia molecular y un incremento notable en el muestreo taxonómico y geográfico en estudios sobre su sistemática han resultado en la descripción de un gran número de géneros y especies nuevas de gymnoftálmidos (particularmente en Cercosaurinae) en años recientes. Aquí describimos un nuevo género y especie de lagarto cercosaurino con fenotipo cocodriloide, del Escudo Guayanés venezolano, a partir de análisis filogenéticos moleculares y caracteres morfológicos. Kataphraktosaurus gen. nov. se distingue de todos los demás géneros de Cercosaurinae por su combinación única de caracteres morfológicos que incluye un patrón de folidosis dorsal heterogéneo, con escamas agrandadas y fuertemente aquilladas formando dos filas paravertebrales, escamas ventrales y subcaudales imbricadas y fuertemente aquilladas, escamas cefálicas grandes y simétricas, ausencia de escama postmental, 
disco palpebral translúcido y dividido, cola ligeramente comprimida, todos los dedos con uñas, y solo seis poros femorales (tres en cada muslo) insertos en medio de una agrupación de pequeñas escamas. Este género, descrito como monotípico, solo incluye a Kataphraktosaurus ungerhamiltoni sp. nov., conocida por un espécimen y cuya diagnosis consta del mismo conjunto de caracteres mencionados para el género. Los hábitos crípticos de esta especie y lo remoto de la localidad tipo pueden explicar el hecho de que sólo se conozca un ejemplar. Siguiendo los criterios de la Unión Internacional para la Conservación de la Naturaleza, asignamos a la nueva especie la categoría de Datos Insuficientes.

Palabras clave: Amazonia, biodiversidad, cuenca del Orinoco, filogenia, Neotrópico, reptil, sistemática, taxonomía

\section{Introduction}

The lizard family Gymnophthalmidae includes 267 extant species from 52 genera distributed throughout the Neotropics (Uetz et al. 2020). Convergence of many morphological characters in different gymnophthalmid lineages, the rarity of some taxa in museum collections, and the lack of sampling in large geographical areas have resulted in a rather complicated and unstable taxonomy. Most of the original taxonomic arrangements within Gymnophthalmidae, which were only based on morphology (e.g., Burt \& Burt 1931; Ruibal 1952; Uzzel 1966) changed dramatically in the last two decades. The pioneer molecular phylogeny of Pellegrino et al. (2001) represents the beginning of a new age in Gymnophthalmidae systematics. This is characterized by a constant increase in taxon and geographic sampling that have led to taxonomic revisions and rearrangements to accommodate newly discovered species and phylogenetic relationships, while ensuring a monophyletic taxonomy (e.g., Castoe et al. 2004; Doan and Castoe 2005; Goicoechea et al. 2012; Pyron et al. 2013; Kok 2015; Torres-Carvajal et al. 2015, 2016; Goicoechea et al. 2016; Marques-Souza et al. 2018; Moravec et al. 2018; Pellegrino et al. 2018; Sánchez-Pacheco et al. 2018; Fang et al. 2020; Lehr et al. 2020; Vásquez-Restrepo et al. 2020).

Gymnophthalmidae is subdivided into subfamilies_-sometimes considered as tribes (Pellegrino et al. 2001; Goicoechea et al. 2016) — of which Cercosaurinae is the most species-rich, with about half of all recognized gymnophthalmid species. Currently, the more than 150 Cercosaurinae species are grouped in 21 genera (TorresCarvajal et al. 2016; Moravec et al. 2018; Sánchez-Pacheco et al. 2018; Lehr et al. 2019, 2020; Fang et al. 2020; Mamani et al. 2020; Parra et al. 2020; Torres-Carvajal et al. 2020; Vásquez-Restrepo et al. 2020). Within this rich subfamily, some linages have evolved a striking phenotype, presumably adapted to aquatic or semi-aquatic life. It includes a streamlined body with pointed snout, compressed tail, heterogeneous dorsal and lateral scalation, sometimes with enlarged tubercles, and strongly keeled scales forming crests on body and tail (i.e., crocodile-like morphology, hereafter CLM as in Marques-Souza et al. 2018). This combination of morphological characters is present in members of the genera Echinosaura, Gelanesaurus, Magdalenasaura, Neusticurus, Potamites (Uzzell 1965; 1966; Doan and Castoe 2005; Torres-Carvajal et al. 2016; Marques-Souza et al. 2018; Fang et al. 2020), and the two monotypic genera Centrosaura and Rheosaurus, which were recently erected by Vásquez-Restrepo et al. (2020) to remedy the polyphyly of Echinosaura. This CLM phenotype has evolved at least four independent times in the evolutionary history of Cercosaurinae, is apparently modulated by ecological and environmental selective pressures, and may be linked to the development of the Pebas Lake in western Amazonia during the Miocene (Marques-Souza et al. 2018). In this study, we report our discovery of a new CLM gymnophthalmid from the western Guiana Shield in Venezuela. The results of our detailed morphological and genetic comparisons, including phylogenetic analysis, indicate that the specimen corresponds to a new stream lizard species, which is not nested within any of the current described Cercosaurinae genera. To maintain a monophyletic taxonomy, while preserving phenotypic diagnosis of current genera within the subfamily, we create a new genus for this new species.

\section{Material and methods}

Fieldwork. The only specimen collected and its associated data resulted from our fieldwork between 13 and 16 July 2010, in a rainforest area on the northwestern foothill of the Serranía del Cuao, Amazonas state, Venezuela (Fig. 1). At this location, we (CLBA, FJMRR, and SCF) performed diurnal and nocturnal visual surveys for herpetofauna and georeferenced the collection sites using a GPS receiver Garmin 60CSX with datum WGS 84. The specimen was captured manually and transported to an improvised laboratory in the field, where it was photographed in life (we 
used these photographs to describe its coloration). After photographed, it was anesthetized and euthanized with an overdose of topical benzocaine solution $(50 \mathrm{mg} / \mathrm{g})$, fixed in a $10 \%$ formalin solution, and preserved in $70 \%$ ethanol. We dissected a sample of muscular tissue from the right thigh prior to fixation and preserved it in $95 \%$ ethanol for molecular analyses.

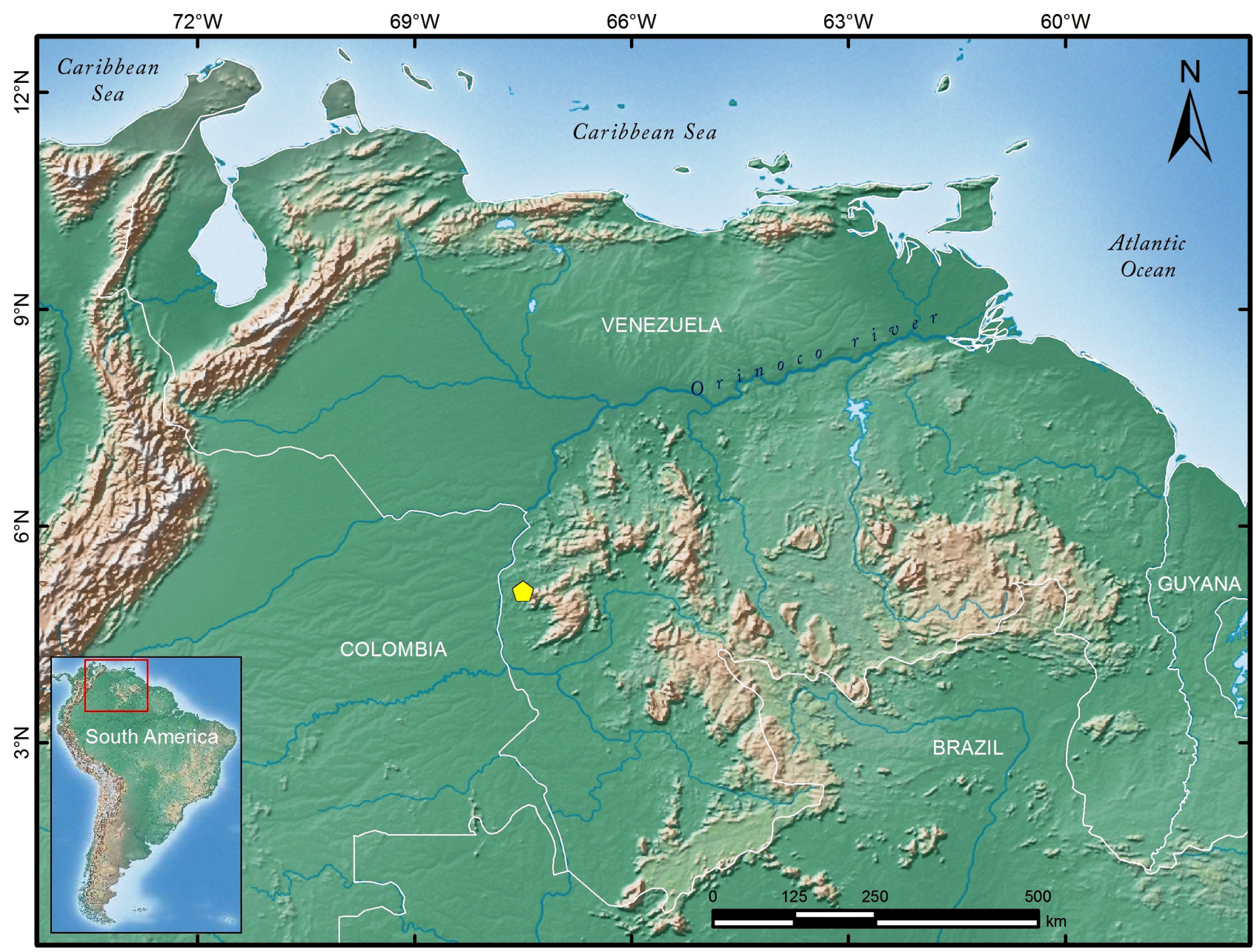

FIGURE 1. Map of Venezuela indicating the geographic position of Caño Bejuco (yellow pentagon), near Tobogán del Cuao, Autana municipality, Amazonas state, Venezuela, type locality of Kataphraktosaurus ungerhamiltoni gen. nov., sp. nov.

Morphology. The holotype was deposited at the Museo de Historia Natural La Salle (MHNLS), Caracas, Venezuela. For comparisons with all other genera of crocodile-like gymnophthalmids, we used morphological descriptions from the literature (Boulenger 1890, 1911; Barbour 1924; Uzzell 1965, 1966; Fritts \& Smith 1969; Fritts et al. 2002; Köhler et al. 2004; Donnelly et al. 2006; Lotzkat et al. 2012; Fang et al. 2020; Vásquez-Restrepo et al. 2020). We followed Kok et al. (2018) and Vásquez-Restrepo et al. (2020) for morphological description format, pholidotic nomenclature, and scale counts. Scale counts and measurements were made by the first author under a stereomicroscope; bilateral meristic and qualitative characters were recorded from both sides and are presented as left/right. Morphometric measurements were taken with a caliper to the nearest $0.1 \mathrm{~mm}$, except limbs and tail that were measured with a piece of string and a ruler. Measurements were taken as follows: snout-vent length (SVL), from snout tip to anterior margin of vent; neck length (NL), from posterior margin of tympanum to anterior insertion of forelimb; axilla-groin distance (AGD), from posterior border of arm insertion to anterior border of leg insertion; tail length (TL), from posterior margin of vent to tail tip; head length (HL), from tip of snout to posterior margin of tympanum; head width (HW), at the maximum width of the head; head depth (HD), at the maximum depth of the head; snout length (SL), from snout tip to anterior corner of eye; forelimb length (FL), from axilla to tip of $4^{\text {th }}$ finger claw; hind limb length (HiL), from groin to tip of $4^{\text {th }}$ toe claw.

Molecular and taxon sampling. Following previous molecular studies on gymnophthalmid systematics (e.g., Pellegrino et al.2001; Torres-Carvajal et al.2016; Vásquez-Restrepo et al.2020), we selected four gene fragments for 
our phylogenetic analysis: three mitochondrial (mtDNA; 12S and 16S rRNAs, and ND4) and one nuclear (nuDNA; C-MOS). In addition to the new sequences generated in this study from our new species, we obtained from GenBank (http://www.ncbi.nlm.nih.gov/genbank) sequences of these four markers for 77 terminals representing 20 genera of Cercosaurinae, and eight species of the other five subfamilies of Gymnophthalmidae (Bachiinae, Ecpleopodinae, Gymnophthalminae, Rhachisaurinae, and Riolaminae). We used Alopoglossus viridiceps (Alopoglossidae) to root all trees.

DNA extraction, amplification, and sequencing. We extracted genomic DNA from a $95 \%$ ethanol-preserved tissue sample of thigh muscle using the Wizard ${ }^{\circledR}$ Genomic DNA Purification Kit (Promega Corporation) and following the manufacturer's protocol. Polymerase chain reactions (PCR) for DNA amplification were performed in a final volume of $25 \mu \mathrm{L}$, using $2 \mu \mathrm{L}$ extracted DNA, $1.25 \mu \mathrm{L}$ of each forward and reverse primers, $8 \mu \mathrm{L}$ of MasterMix, and $12.5 \mu \mathrm{L} \mathrm{H}_{2} \mathrm{O}$. Negative controls were run on all amplifications to check for contamination. Primers and reaction conditions used to amplify the four DNA markers are presented in the Table 1. PCR products were inspected in $1 \%$ agarose gels by horizontal electrophoresis. Cycle sequencing reactions were performed by Macrogen Labs (Macrogen Inc., Korea). All PCR products were sequenced in both forward and reverse directions, to check for potential errors. We assembled contigs and inspected chromatograms using Sequencher 4.8 (GeneCodes, Ann Arbor, MI, USA). Finally, we performed BLAST queries (https://blast.ncbi.nlm.nih.gov/Blast.cgi) of the new sequences to verify their identity and to discard contaminations or mislabeling errors. GenBank accession codes of all analyzed sequences (including newly generated ones) are in Appendix 1.

TABLE 1. Primers and PCR conditions used to amplify the four gene fragments (three mitochondrial and one nuclear) used in this study.

\begin{tabular}{|c|c|c|}
\hline Gene & $\begin{array}{l}\text { Primer name, sequence, and source } \\
\text { (forward/reverse) }\end{array}$ & PCR conditions \\
\hline \multirow[t]{2}{*}{$12 S$} & $\begin{array}{c}\text { 12SA-L (Palumbi } \text { et al. 1991) } \\
\text { AAACTGGGATTAGATACCCCACTAT }\end{array}$ & $\begin{array}{c}95^{\circ} \mathrm{C} / 15 \mathrm{~s} ; \\
35 \times\left(95^{\circ} \mathrm{C} / 30 \mathrm{~s}, 50^{\circ} \mathrm{C} / 30 \mathrm{~s}, 72^{\circ} \mathrm{C} / 1 \mathrm{~min}\right) ; \\
72^{\circ} \mathrm{C} / 10 \mathrm{~min}\end{array}$ \\
\hline & $\begin{array}{c}\text { 12SB-H (Palumbi et al. 1991) } \\
\text { GAGGGTGACGGGCGGTGTGT }\end{array}$ & \\
\hline \multirow[t]{2}{*}{$16 S$} & $\begin{array}{l}\text { 16Sar-5' (Palumbi et al. 1991) } \\
\text { CGCCTGTTATCAAAAACAT }\end{array}$ & $\begin{array}{c}95^{\circ} \mathrm{C} / 15 \mathrm{~s} \\
35 \times\left(95^{\circ} \mathrm{C} / 30 \mathrm{~s}, 50^{\circ} \mathrm{C} / 30 \mathrm{~s}, 72^{\circ} \mathrm{C} / 1 \mathrm{~min}\right) ; \\
72^{\circ} \mathrm{C} / 10 \mathrm{~min}\end{array}$ \\
\hline & $\begin{array}{l}\text { 16Sbr-3' (Palumbi et al. 1996) } \\
\text { CCGGTCTGAACTCAGATCACGT }\end{array}$ & \\
\hline \multirow[t]{2}{*}{ ND4 } & $\begin{array}{c}\text { ND4 (Arévalo et al. 1994) } \\
\text { CACCTATGACTACCAAAAGCTCATGTAGAAGC }\end{array}$ & $\begin{array}{c}94^{\circ} \mathrm{C} / 3 \mathrm{~min} \\
35 \times\left(94{ }^{\circ} \mathrm{C} / 45 \mathrm{~s}, 50^{\circ} \mathrm{C} / 45 \mathrm{~s}, 72^{\circ} \mathrm{C} / 1 \mathrm{~min}\right) ; \\
72^{\circ} \mathrm{C} / 6 \mathrm{~min}\end{array}$ \\
\hline & $\begin{array}{c}\text { LEU (Arévalo et al. 1994) } \\
\text { CATTACTTTTACTTGGATTTGCACCA }\end{array}$ & \\
\hline \multirow[t]{2}{*}{ C-MOS } & $\begin{array}{c}\text { G73 (Saint et al. 1998) } \\
\text { GCGGTAAAGCAGGTGAAGAAA }\end{array}$ & $\begin{array}{c}94{ }^{\circ} \mathrm{C} / 2 \mathrm{~min} ; \\
35 \times\left(94{ }^{\circ} \mathrm{C} / 1 \mathrm{~min}, 56^{\circ} \mathrm{C} / 45 \mathrm{~s}, 72{ }^{\circ} \mathrm{C} / 1 \mathrm{~min}\right) \\
72{ }^{\circ} \mathrm{C} / 7 \min \end{array}$ \\
\hline & $\begin{array}{c}\text { G74 (Saint et al. 1998) } \\
\text { TGAGCATCCAAAGTCTCCAATC }\end{array}$ & \\
\hline
\end{tabular}

Phylogenetic analyses. We used MUSCLE (Edgar 2004) under default settings as implemented in AliView 1.14 (Larsson 2014) to generate multiple sequence alignments of each marker separately. These alignments were concatenated with SequenceMatrix 1.7.8 (Vaidya et al. 2011). The best-fit partition scheme and corresponding models of nucleotide substitution for each partition were simultaneously assessed in PartitionFinder2 (Lanfear $e t$ al. 2017) according to the corrected Akaike Information Criterion (AICc). For this, we considered branch lengths as linked and evaluated three partition schemes: 1) all four markers combined; 2) mtDNA and nuDNA; and 3) each marker independently. We performed maximum likelihood (ML) tree searches implementing the optimal partition scheme and substitution models in Garli 2.01 (Zwickl 2006). To increase the exhaustiveness of tree searches, we 
performed 500 independent tree searches, each with 175 attachments per branch (twice the number of terminals of the dataset, plus one), run termination threshold of 10,000 generations without significant improvement in likelihood, and maximum SPR distance of six branches away from original location. Other settings were set on default values. We also computed bootstrap support (BS) in Garli 2.01 via 1,000 pseudoreplicates under the same settings used for the tree searches. Clade frequencies of bootstrap pseudoreplicates were plotted onto the most likely tree with SumTrees 4.3.0 in DendroPy 4.3.0 (Sukumaran \& Holder 2010, 2017). We performed all searches in the CIPRES Science Gateway (Miller et al. 2010). In addition to phylogenetic analysis, we estimated uncorrected pairwise genetic distances of 16S using uniform rates and default parameters in MEGA 7.0.14 (Kumar et al. 2016). We used this molecular marker because it is the best represented in our dataset (Appendix 1) and also the most commonly used to assess genetic divergence among lizards.

\section{Results}

Phylogenetic reconstruction and relationships. Our final concatenated dataset consists of a total of 1,926 bp. The best-fit partition scheme and optimal evolution models $(\operatorname{lnL}=-36,980.84 ; \mathrm{AICc}=74,438.40)$ for our dataset includes four subsets, each one corresponding to a single gene, with $\mathrm{GTR}+\mathrm{I}+\mathrm{G}$ as the optimal nucleotide substitution model for $12 \mathrm{~S}, 16 \mathrm{~S}$, and ND4, and TVM $+\mathrm{G}$ for C-MOS. The most likely inferred topology (Fig. 2; $\operatorname{lnL}=-36,728.47$ ) is well resolved. Within a monophyletic Cercosaurinae $(\mathrm{BS}=92 \%)$, all sampled genera with more than one species are monophyletic and with BS $>75 \%$. The exception is Proctoporus, which is paraphyletic with respect to Cercosaura, Dendrosauridion, Potamites, and Selvasaura. Most deeper nodes have BS $<70 \%$. Our specimen (MHNLS 19960) is nested within Cercosaurinae (BS $=92 \%)$ as sister of all cercosaurines except Placosoma and Neusticurus $(\mathrm{BS}=$ $58 \%$; Fig. 2). Uncorrected pairwise 16S distances between our specimen and all other cercosaurins sampled in the phylogeny range between $8.8-15.1 \%$.

Morphology. The specimen MHNLS 19960 shows a unique combination of morphological characters that sets it apart from all other species and genera of Cercosaurinae. The main diagnostic characters are (Figs. 4-7): heterogeneous dorsal scalation with enlarged and strongly keeled scales, ventral and subcaudal scales slightly imbricated and strongly keeled, large and symmetrical cephalic scales, absence of postmental scale, palpebral disc translucent and divided, tail slightly compressed, all digits clawed, and only six femoral pores (three at each hindlimb) inserted in a clump of small scales. To avoid repetition, detailed morphological descriptions of qualitative and quantitative characters and comparisons with relevant taxa are provided below.

Data integration. The best explanation for the phylogenetic relationships and pattern of phenotypic variation of MHNLS 19960 is that this specimen belongs to a previously unknown species that is not nested within or sister of any of the currently recognized genera of Cercosaurinae. To formalize our discovery and to preserve a monophyletic taxonomy, we describe and name, according to the rules of the ICZN (1999), a new species and genus.

\section{Taxonomy}

\section{Kataphraktosaurus gen. nov.}

Type species: Kataphraktosaurus ungerhamiltoni sp. nov.

Definition. This new genus is defined by the unique combination of the following characters: (1) Dorsal scales heterogeneous, with large, longitudinally keeled scales intercalated by small irregular, granular to flat scales; (2) dorsal surface of head with large, weakly keeled, symmetrical scales; (3) two subtriangular internasals, each one as long as wide; (4) two large pentagonal frontonasals, more than two times longer than wide; (5) prefrontals absent; (6) frontal scale single, hexagonal, double-keeled; (7) two pentagonal frontoparietals, single-keeled; (8) interparietal large, subpentagonal, well-differentiated; (9) parietals large, polygonal, paired, flanking interparietal; (10) occipitals not differentiated; (11) temporal scales not differentiated; (12) lower eyelid developed, with palpebral disc divided into several unpigmented scales; (13) postmental absent; (14) three pairs of enlarged chin shields; (15) ventral scales pentagonal, keeled, mucronate, imbricated; (16) tail slightly compressed; (17) forelimbs and hind limbs pentadactyl; (18) digits clawed; (19) femoral pores inserted in a clump of 4-5 scales. 


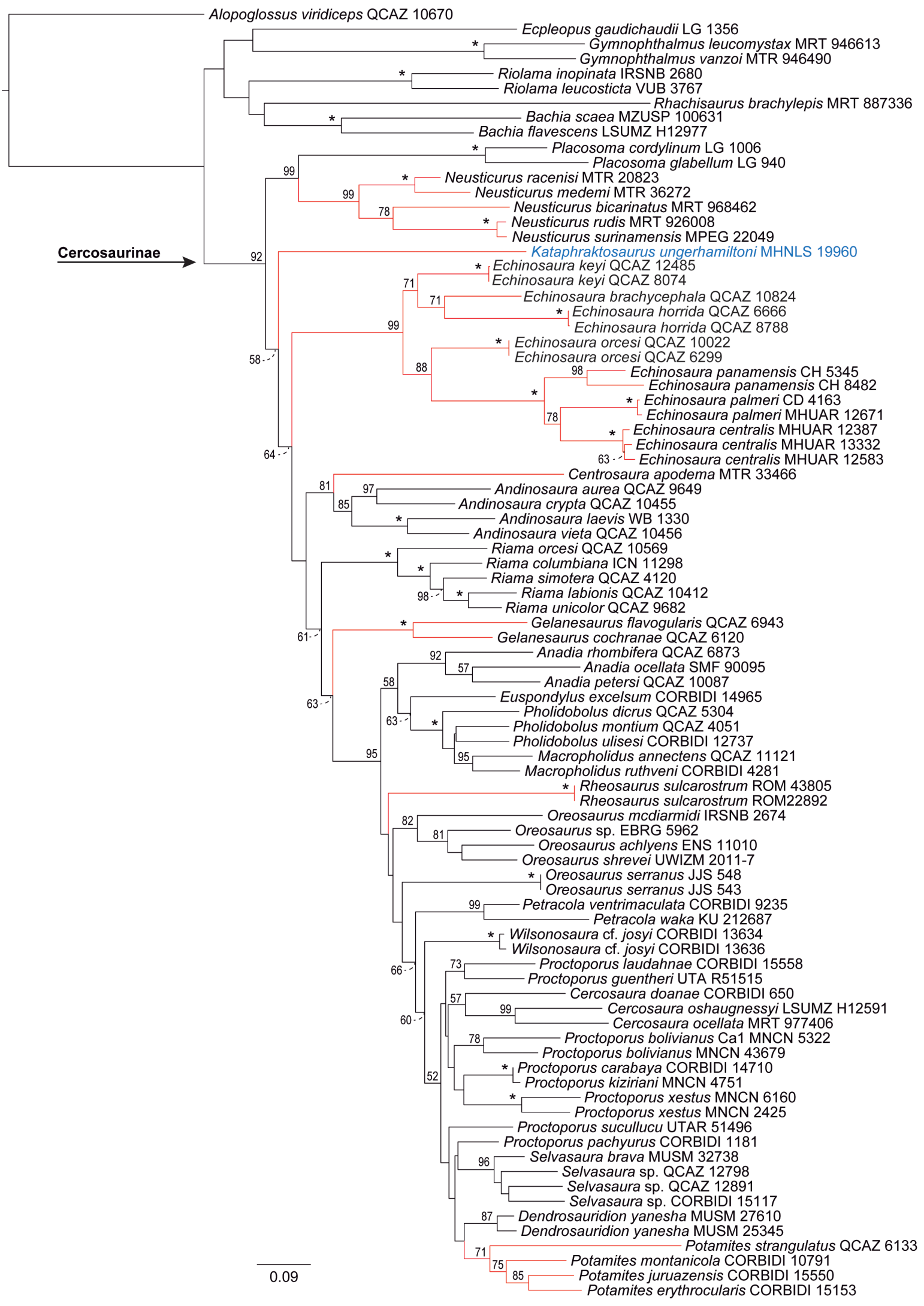

FIGURE 2. Maximum likelihood tree $(\mathrm{lnL}=-36,728.472)$ inferred from an aligned concatenated matrix of $1,926 \mathrm{bp}$ including gene fragments of 12S, 16S, ND4 and C-MOS, depicting the phylogenetic relationships of Kataphraktosaurus ungerhamiltoni gen. nov., sp. nov. (in blue font) within Cercosaurinae. Branches in red indicate species with crocodile-like morphology. Numbers above nodes represent bootstrap support values inferred from 1,000 pseudoreplicates; values below $50 \%$ are not included; asterisks represent $100 \%$ bootstrap support. 


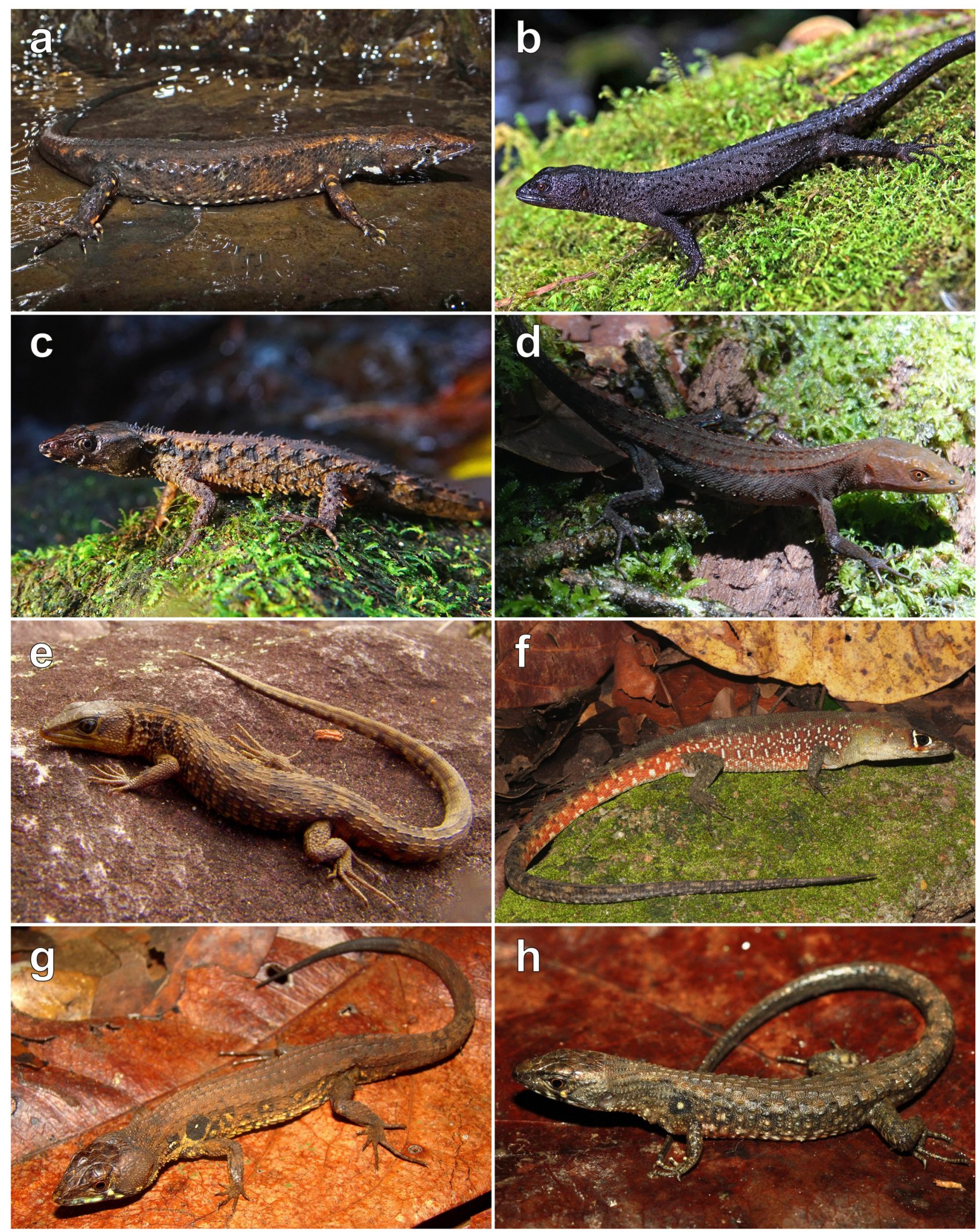

FIGURE 3. Some Cercosaurinae lizards with crocodile-like morphology: (a) Centrosaura apodema, from La Alfombra, Pérez Zeledón, Costa Rica; (b) Echinosaura brachycephala, from Mindo, Pichincha, Ecuador; (c) Echinosaura horrida, from Puerto Quito, Pichincha, Ecuador; (d) Gelanesaurus flavogularis, from Archidona, Napo, Ecuador; (e) Neusticurus arekuna, from Chivatón, Bolívar, Venezuela; (f) Neusticurus medemi, from Las Pavas, Amazonas, Venezuela; (g) Potamites ecpleopus, from Juami river, Amazonas, Brazil; (h) Potamites erythrocularis, from Inambari, Madre de Dios, Peru. Photos: C.L. Barrio-Amorós (a-f), F.J.M. Rojas-Runjaic (g), and G. Chávez (h). 
Diagnosis. Apart from the new genus described herein, Cercosaurinae includes 21 genera: Anadia, Andinosaura, Centrosaura, Cercosaura, Dendrosauridion, Echinosaura, Euspondylus, Gelanesaurus, Macropholidus, Magdalenasaura, Neusticurus, Oreosaurus, Petracola, Pholidobolus, Placosoma, Potamites, Proctoporus, Rheosaurus, Riama, Selvasaura, and Wilsonosaura (Torres-Carvajal et al. 2016; Moravec et al. 2018; SánchezPacheco et al. 2018; Lehr et al. 2019, 2020; Fang et al. 2020; Vásquez-Restrepo et al. 2020). Among them, only Centrosaura, Echinosaura, Gelanesaurus, Magdalenasaura, Neusticurus, Potamites and Rheosaurus have heterogeneous dorsal scalation (i.e., presence of enlarged dorsal tubercular, spine-like, or keeled scales intermixed with small flat or granular scales; Fig. 3). Therefore, we restrict our comparisons to these seven genera.

Kataphraktosaurus is readily distinguished from Centrosaura, Echinosaura, Gelanesaurus, Magdalenasaura, Neusticurus, and Potamites by lacking a postmental scale (present in all the species of these genera, except in E. brachycephala, where it can be absent or reduced); having pentagonal, mucronate, strongly keeled, imbricate ventral scales (squared or rounded squares, usually flat, and not imbricated; only keeled in E. brachycephala, E. centralis, and E. horrida); and six femoral pores (total count) in males ( $\geq 6$ in Echinosaura, $\geq 10$ in Potamites, $\geq 20$ in Centrosaura and Magdalenasaura, and $>30$ in Gelanesaurus and Neusticurus). In addition, Kataphraktosaurus differs from Centrosaura by having symmetrical paired intersanals (not paired and asymmetrical), paired frontonasals (several small irregular scales in the frontonasal region), prefrontals absent (paired), a single frontal (divided), and femoral pores inserted in a clump of scales (in the center of a single scale). From Echinosaura, it differs by its smaller SVL (adult male $49 \mathrm{~mm} v s .>70 \mathrm{~mm}$ in Echinosaura) and by having large and well-defined interparietal and parietals (several irregular and small scales on the parietal region), three pairs of chin shields (usually one pair), two ventral scales per tail verticil (three or more scales), and femoral pores inserted in a clump of scales (in the center of a single scale). From Gelanesaurus by having homogeneous brown coloration around the nostril (a conspicuous blackish spot surrounding nostril), two continuous longitudinal ridges on dorsum (four), heterogeneous scales on the flanks of the body, with enlarged keeled scales (scales homogeneous, not tuberculated), gular scales keeled and juxtaposed (smooth and imbricated), and tail scales arranged in verticils (not arranged in verticils). From Magdalenasaura, it differs by having weakly keeled and wrinkled dorsal scales on head (smooth), small asymmetrical occipitals (large, paired, and symmetrical), enlarged strongly keeled dorsal scales (smooth to weakly keeled, not tuberculated), gular scales keeled and juxtaposed (smooth and imbricated), and femoral pores inserted in a clump of scales (in the center of a single scale). From Neusticurus, it can be distinguished by lacking prefrontals (present) and having paired internasals (absent) and a slightly compressed tail (strongly compressed). From Potamites, it differs by lacking prefrontals (present), having internasals (absent), palpebral disc divided into several scales (undivided), and by its acuminate and moderately long snout (blunt and short snout). Kataphraktosaurus shares with Rheosaurus the absence of postmental scale and the presence of strongly keeled ventral and subcaudal scales. However, it can be readily distinguished from the later by lacking prefrontal scales (present) and by having: a pair of frontonasals (three); small, irregular and not differentiated occipitals (large and symmetrical); rostral and mental scales smooth (grooved); six infralabials (four); supra and infralabials smooth (supralabials keeled and infralabials with central striation); two continuous longitudinal ridges on dorsum (four); cloacal plate with four large smooth scales (six, keeled); six femoral pores in adult males (14-15 femoral pores); and femoral pores inserted in a clump of 4-5 scales (in clumps of 3-4 scales).

Content: Monotypic. The only known species in this genus is Kataphraktosaurus ungerhamiltoni sp. nov., which is described below.

Geographic distribution: Western Guiana Shield region, in the western foothills of the Serranía del Cuao, Amazonas state, Venezuela.

Etymology: The generic name Kataphraktosaurus (gender masculine) is derived from the combination of the

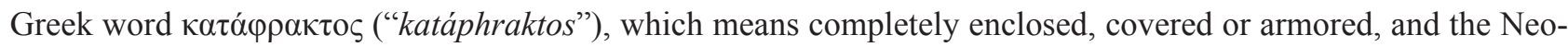
Latin -saurus—derived from the ancient Greek oaṽoos ("saûros")—, which means lizard. This name highlights the "armored" condition of this lizard as a result of the strongly keeled, tuberculated, and pointed scales that cover its body. 


\section{Kataphraktosaurus ungerhamiltoni sp. nov.}

(Figures 4-7)

Suggested common name in English: Cuao's stream spiny lizard

Suggested common name in Spanish: Lagartija espinosa del Cuao

Holotype. Adult male, MHNLS 19960 (field number AJC 3014), from Caño Bejuco, near Tobogán del Cuao, Autana municipality, Amazonas state, Venezuela $\left(5^{\circ} 05^{\prime} 58^{\prime \prime} \mathrm{N}, 67^{\circ} 29^{\prime} 54^{\prime \prime} \mathrm{W}\right.$; elevation $\left.124 \mathrm{~m}\right)$, collected on 14 July 2010, by C.L. Barrio-Amorós, F.J.M. Rojas-Runjaic, and S. Castroviejo-Fisher.

Definition. This species is defined by the same character states listed for the genus, in combination with the following characteristics: (1) small body size (49 mm SVL; female unknown); (2) snout acuminate, moderately long; (3) palpebral disc with five to seven large palpebral scales; (4) six supralabials; (5) six infralabials; (6) paravertebral rows of enlarged scales continuous; (7) collar distinct, containing six enlarged scales; (8) ventral scales arranged in 20 transverse and eight longitudinal rows; (9) six femoral pores (three on each side) in males (female unknown); (10) tail with six pairs of longitudinal ridges around it (two dorsal submedian, two dorsolateral, two median laterals, two lower lateral, two ventrolateral, and two ventral submedian); (11) two subcaudal scales by verticil; (12) three keeled scales on the dorsal submedian ridge by verticil; (13) subdigital lamellae on fourth finger 15-16; (14) subdigital lamellae on fourth toe 21-22.

Description of holotype. Adult male in a good state of preservation (Figs. 4-7), with a piece of muscle removed from its right thigh for molecular analyses, and with the following measurements: SVL: $49 \mathrm{~mm}$; HL: $13.6 \mathrm{~mm}$; HW: 8.9 mm; HD: 6.3 mm; SL: 4.7 mm; NL: 9.7 mm; AGD: 21.1 mm; TL: 84.9 mm; FL: $15.6 \mathrm{~mm}$; HLL: $24.8 \mathrm{~mm}$. Head longer than wide (HL/HW: 1.5 ), depressed (HD/HW: 0.7$)$. Snout acuminate in dorsal view and profile, moderately long (SL/HL: 0.4), gently sloping toward top of head (Fig. 4a-d). Tongue deeply bifid, tips smooth, dorsal surface posterior to cleft covered by scale-like papillae. Rostral (Fig. 4a) barely visible from above, smooth, wider than long (tape-like), slightly higher than adjacent supralabials, in contact with internasals dorsally, and with nasals and first pair of supralabials laterally. Internasals two, subtriangular, as long as wide, with weak marginal keels; both scales broadly in contact medially, each one in contact with rostral anteriolaterally, with nasals lateroposteriorly, and with frontonasals posteriorly (Fig. 4a). Frontonasals two, pentagonal, more than two times longer than wide, with some weakly raised sinuous keels longitudinally oriented; both scales broadly in contact medially, with their posterior edges posterolaterally divergent, forming an obtuse angle; each frontonasal is in contact with internasals anteriorly, with nasals and loreals laterally, with pre-supraoculars posterolaterally, and with frontal posteromedially (Fig. 4a). Frontal single, hexagonal, wider anteriorly, with anteromedial and posteromedial vertices convex; its surface with two weakly raised sinuous keels longitudinally oriented; frontal in contact with frontonasals anteriorly, with some small pre-supraoculars anterolateraly, with $1^{\text {st }}$ and $2^{\text {nd }}$ supraoculars posterolaterally, and with frontoparietals posteriorly (Fig. 4a). Supraoculars four, weakly ornamented with sinuous marginal keels; all supraoculars laterally bordered by two-three rows of keeled supraciliars; $1^{\text {st }}$ supraocular subtriangular, in contact with two/three small granular pre-supraoculars anteriorly; $2^{\text {nd }}$ supraocular the largest, subtrapezoidal, medially in contact with frontal, frontoparietal and parietal; $3^{\text {rd }}$ and $4^{\text {th }}$ supraocular the smallest, tubercular, subquadrangular to nearly circular at their base, in contact with parietal (Fig. 4a). Frontoparietals two, pentagonal, wider posteriorly, each one medially crossed by a keel (which comes from the frontal) ended in a rounded tubercle at its posterolateral margin. Interparietal large, almost flat, subpentagonal, with parallel lateral margins and near semicircular posterior margin, projecting farther posteriorly than the parietals; interparietal in contact with frontoparietals anteriorly, parietals laterally, and with numerous small irregular occipital scales posteriorly (Fig. 4a). Parietals two, large, about as wide as interparietal, polygonal (nearly circular), flat, slightly wrinkled, each one in contact with frontoparietal, with $3^{\text {rd }}$ and $4^{\text {th }}$ supraoculars anteriorly, with interparietal medially and with four medium-sized scales laterally and posteriorly (Fig. 4a). Occipital and temporal regions covered by juxtaposed small and medium-sized polygonal keeled scales, being larger and more strongly keeled those aligned behind the eye (Fig. 4a).

Nasal elliptical, wider than high; the one on the left side vertically divided; that on the right side complete; anterior half of nasal smooth, about three times larger than the posterior half; posterior half irregularly wrinkled; nostril completely located on the anterior half, not protruded, furrowed around its anterior margin, slightly directed posterolaterally, barely visible from above (Fig. 4b, d). Loreal region slightly concave, almost vertical. Loreal scale large, polygonal, higher posteriorly, almost flat; loreal in contact with frontonasal dorsally, with nasal anteriorly, with $1^{\text {st }}-3^{\text {rd }}$ supralabial ventrally, and with one preciliar and two/one suboculars posteriorly (Fig. 4b, d). Eyes protuberant; 
pupil round. Palpebral disc translucent, with five to seven large palpebral scales. Suboculars six/five, arranged in a row above supralabials; $1^{\text {st }}$ subocular almost as high as wide, all the posterior ones about two times wider than high. Supralabials six/six, infralabials six/six; supra- and infralabials smooth and tape-shaped. Tympanum slightly recessed (Fig. 4b, d).

Mental smooth, wider than long, rounded anteriorly, concave posteromedially; in contact with $1^{\text {st }}$ pair of infralabials posterolaterally, and with $1^{\text {st }}$ pair of geneials posteromedially. Postmental scale absent (Fig. 4c). Three pairs of large smooth geneials (Fig. $4 \mathrm{c}$ ), $1^{\text {st }}$ and $2^{\text {nd }}$ pair similar in size, $3^{\text {rd }}$ pair about half the size of the $1^{\text {st }}$ and $2^{\text {nd; }}$; $1^{\text {st }}$ pair longer than wide, both broadly in contact medially, laterally in contact with $1^{\text {st }}$ and $2^{\text {nd }}$ infralabials; $2^{\text {nd }}$ pair of geneials longer (left) or slightly longer (right) than wide, medially separated by three small scales, laterally in contact with $2^{\text {nd }}$ and $3^{\text {rd }}$ infralabials; $3^{\text {rd }}$ pair of geneials about as long as wide, medially separated by two rows of small scales, laterally separated from infralabials by one row of small weakly keeled scales. Gular scales keeled, longer than wide, being smaller and weakly keeled those located on the anterior and anteromedial portions of the gular region; progressively larger and stronger keeled laterally and posteriorly; becoming nearly circular, spine-like, and spaced by small granules on the mid-third of the gular region (Fig. 4c); nearly hexagonal, juxtaposed, strongly keeled, and arranged in three transverse rows at the posterior end of that region. Collar distinct, containing six enlarged scales; collar fold naked and conspicuous (Fig. 5b).

Dorsal and lateral surfaces of neck and body covered with heterogeneous scales. Large, strongly keeled and posteriorly pointed scales juxtaposed forming two continuous paravertebral rows, not completely aligned, from occiput to tail base (Fig. 5a). Numerous oblique rows of similar enlarged scales extending posterolaterally from each paravertebral row and through the flanks, to the border of ventral scales. Enlarged scales on these diagonal rows becoming slightly smaller lateroposteriorly, separate from each other in the same row and from enlarged scales of neighboring rows by about two-five small flat or granular scales (Fig. 5a, c).

Ventral scales pentagonal, keeled, mucronate, slightly imbricate, arranged in 20 transverse and eight longitudinal rows; progressively increasing in size from chest to belly; those in the most lateral rows heavily keeled (Fig. 5b). Cloacal plate elliptical, mostly covered by four large smooth scales symmetrically arranged; two medial (anterior and posterior), similar in size, roughly triangular, barely in contact with each other at the center of the plate, and two larger lateral scales, pentagonal, separated from each other by the medial scales (Fig. 5d); anterior margin of the plate delineated by eight small rounded to subtriangular scales. Six femoral pores (three at each hindlimb), in a row separated medially by the two anteriormost scales of the precloacal plate (Fig. 5d). Each femoral pore surrounded by $4-5$ small bulging scales, giving it a flower-like appearance (Fig. $5 \mathrm{~d}$ ).

Tail complete (not regenerated), slightly compressed; dorsal and lateral surfaces covered with heterogeneous scales mainly juxtaposed (Fig. 5e-f); ventral surface with homogeneous enlarged subcaudals, keeled, imbricate, pentagonals (longer than wide), with convex posterior margin (Fig. 5g). Tail with twelve longitudinal ridges around it: two dorsal submedian (paravertebral), two dorsolateral, two median laterals, two lower lateral, two ventrolateral, and two ventral submedian (Fig. 5e-g). Dorsal submedian ridges continuous with paravertebral ones coming from occiput (Fig. 5a); dorsolateral ridges originating above the thighs; all the remaining ridges starting from the base of the tail. Dorsal submedian, dorsolateral, median lateral, and lower lateral ridges formed by a series of increasing-insize scales from the anterior margin of each caudal verticil (Fig. 5e-f), each verticil corresponding to two subcaudal scales (Fig. 5g) and containing three transverse rows of keeled scales at the dorsal submedian ridges; distal scale of dorsal median and dorsolateral ridges of each verticil distinctly overlapping the next verticil (Fig. 5e).

Scales on dorsal surface of forelimbs large, similar in size, strongly keeled, mucronate, slightly imbricate, forming longitudinal rows (Fig. 5a); scales on dorsal surface of hand keeled, forming five rows that individually extend to the tip of each of the five fingers (Fig. 6b). Scales becoming rounded and weakly keeled towards the ventral surface of the forearm; small, flat, polygonal to rounded, and juxtaposed on the palm. Subdigital lamellae on fingers entire, rectangular, much wider than long. Subdigital lamellae on fourth finger 15/16 (Fig. 6a). Scales on dorsal surface of hind limbs heterogeneous, strongly keeled, lanceolate to mucronate, slightly imbricate, forming longitudinal rows (Fig. 5a); scales on dorsal surface of foot keeled, forming five rows, individually extending to the tip of each of the five fingers (Fig. 6d). Scales becoming weakly keeled towards the ventral surface of the thigh and shank; small, flat, polygonal to rounded, and juxtaposed on the sole. Subdigital lamellae on toes generally divided on the proximal half, entire on the distal half, rectangular, wider than long. Subdigital lamellae on fourth toe 21/22 (Fig. 6c). All digits clawed. 


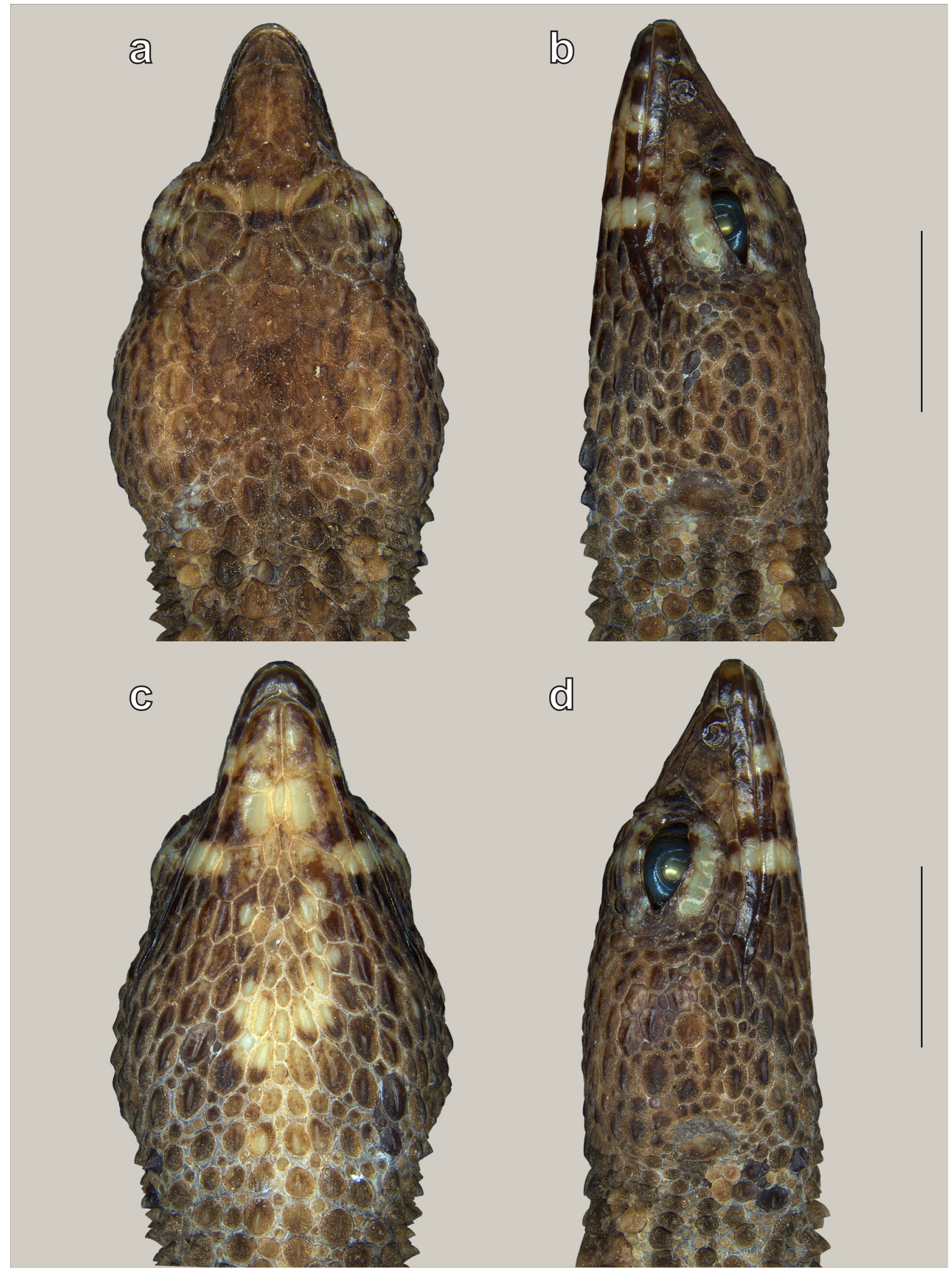

FIGURE 4. Male holotype of Kataphraktosaurus ungerhamiltoni gen. nov., sp. nov. (MHNLS 19960) in preservative. Dorsal (a), left lateral (b), ventral (c), and right lateral (d) views of the head. Scale bars represent 5 mm. Photos: F.J.M. Rojas-Runjaic. 

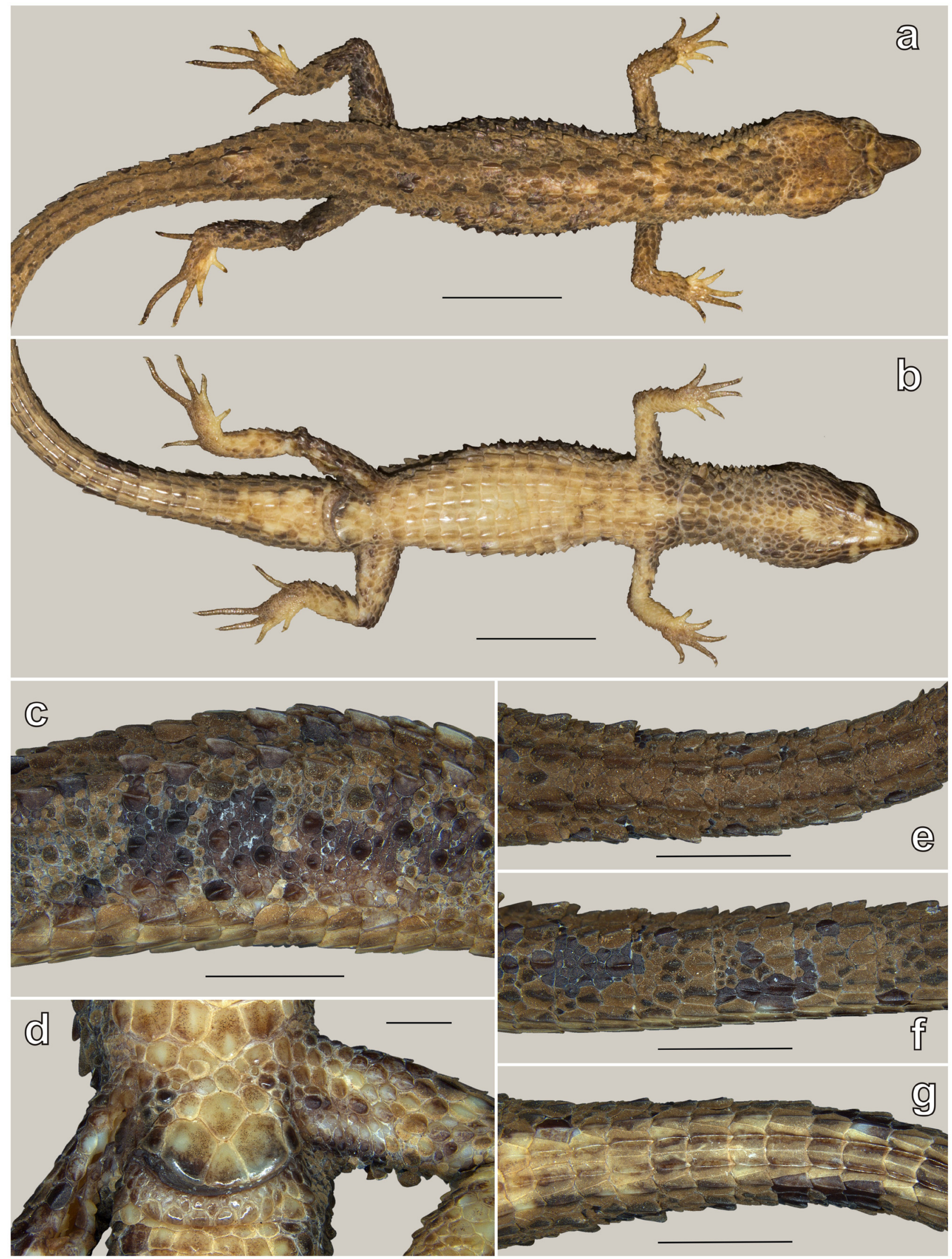

FIGURE 5. Male holotype of Kataphraktosaurus ungerhamiltoni gen. nov., sp. nov. (MHNLS 19960) in preservative. Dorsal (a) and ventral (b) views of the body; lateral view of the trunk (c); cloacal plate and undersurface of thighs (d); dorsal (e), lateral (f), and ventral (g) views of the tail. Scale bars represent $10 \mathrm{~mm}(\mathrm{a}-\mathrm{b}), 5 \mathrm{~mm}$ (c, e-g), and $2 \mathrm{~mm}$ (d). Photos: L.Y. Echevarría (a-b) and F.J.M. Rojas-Runjaic (c-g). 


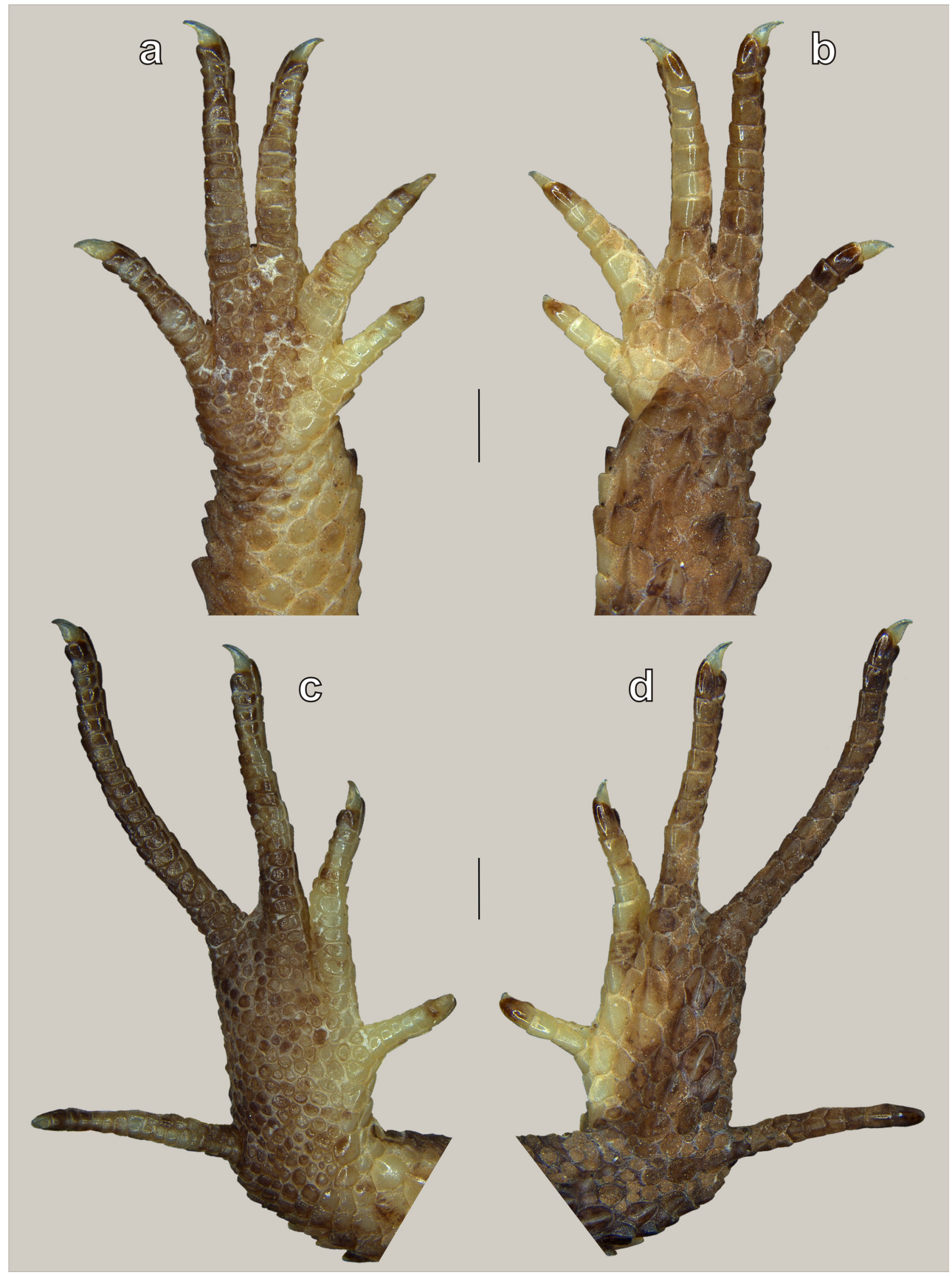

FIGURE 6. Male holotype of Kataphraktosaurus ungerhamiltoni gen. nov., sp. nov. (MHNLS 19960) in preservative. Ventral (a) and dorsal (b) views of the right hand; ventral (c) and dorsal (d) views of the right foot. Scale bars represent $1 \mathrm{~mm}$. Photos: F.J.M. Rojas-Runjaic. 
Coloration of holotype in life and preservative. In life (Fig. 7a), dorsal background reddish-brown, with some poorly defined, irregular, dark brown, and light brown blotches. Head with a well-defined light brown interocular stripe, finely bordered with dark brown. An ill-defined light brown dorsolateral stripe on each side extending from the posterodorsal corner of the eye to the neck. Supra and infralabial scales darker, with four-five pale vertical stripes; the most posterior the largest, dorsally reaching the eye and ventrally the geneials. Palpebral disc translucent. Iris copper. Ventrally, with some small irregular white spots on the geneials and an irregular ocher spot medially extending from the gular region to the chest; rest of the gular region dark brown. Chest, belly, undersurface of forearms, cloacal plate and anterior portion of tail dirty ocher; ventral surface of thighs and shanks variegate, with pale ocher and dark brown. First and second digits of hands and feet pale yellow. Palms and soles grayish brown. In preservative (after nine years preserved in ethanol $70 \%$; Figs. 4-6), the general color pattern is quite similar; the reddish brown background has faded into light brown; the irregular dark brown blotches maintain a similar intensity but turned slightly more contrasting with the background color; light brown blotches turned yellowish white. Ventral surfaces ocher colored in life, turned dirty white.

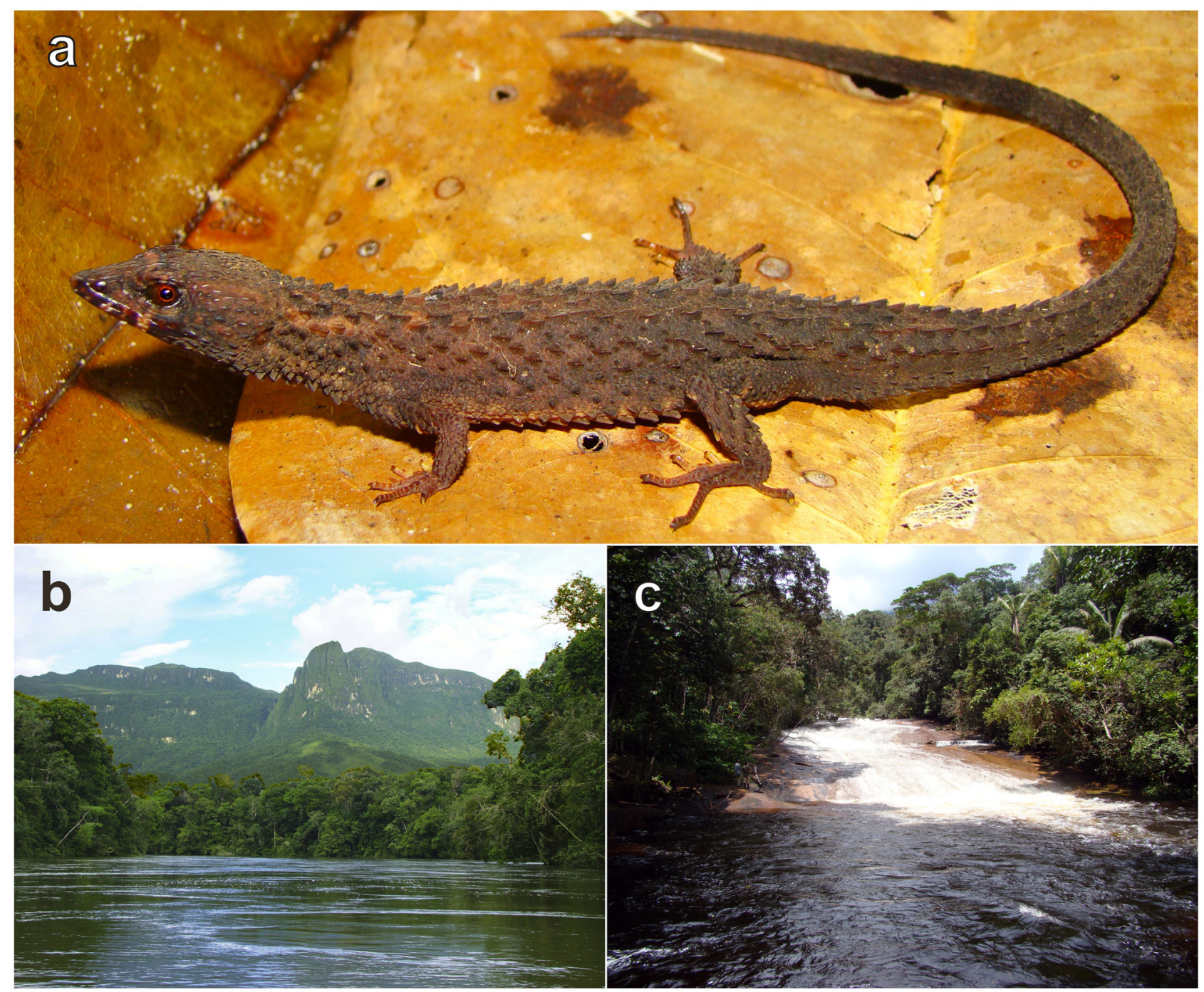

FIGURE 7. Male holotype of Kataphraktosaurus ungerhamiltoni gen. nov., sp. nov. (MHNLS 19960) in life (a). Western slope of Serranía del Cuao seen from the Cuao River (b) and Tobogán del Cuao in Caño Bejuco (c), Amazonas state, Venezuela. Photos: F.J.M. Rojas-Runjaic.

Distribution and natural history. Kataphraktosaurus ungerhamiltoni is only known from its type locality near Tobogán del Cuao, in the foothills of Serranía del Cuao, northwestern Amazonas state, Venezuela, at $124 \mathrm{~m}$ asl (Figs. 1, 7b-c). However, it is likely that its distribution extends through similar habitats across the slopes of the Cuao-Sipapo mountain system in northern Amazonas state. We found the only known specimen during the night, sleeping among the leaf litter accumulated next to a pool of a fast-flowing rocky stream in a pristine tropical humid 
forest. We presume it is a diurnal and semi-aquatic species that inhabits in the leaf litter of the forests adjacent to black water streams.

Etymology. This species is named in honor of Mr. Felix Unger-Hamilton, in recognition of his support and interest in the study and conservation of Venezuelan biodiversity and the description of new species.

\section{Discussion}

Kataphraktosaurus is the twenty-second genus of Cercosaurinae and the eighth with CLM. CLM has been interpreted as a series of morphological changes related to aquatic or semiaquatic lifestyles (Uzzell 1966; Donnelly et al. 2006; Marques-Souza et al. 2018). It has been hypothesized that this phenotype evolved at least four times within Cercosaurinae (Marques-Souza et al. 2018). These last authors further argued that a compressed tail, a double tail crest, and vertically enlarged tubercle-like scales on dorsum may improve locomotion in water by maximizing effort through undulatory movements to swim. However, according to the literature (Uzzell 1966; AltamiranoBenavides et al. 2013; Fang et al. 2020) and our own field experience, some species exhibiting CLM phenotype do not appear to have a semi-aquatic life style (for example, some Echinosaura and all the specie of Gelanesaurus and Magdalenasaura), as they are often found dwelling into the forest—on leaf litter or rotten logs—or in rocky areas next to streams and creeks, but not directly in them. We suggest that future research should evaluate whether there is a causal connection between aquatic behavior and characters potentially associated with it (e.g., compressed tail, double tail crest) by independently reconstructing the evolution of those characters (Wenzel \& Carpenter 1994). Furthermore, it also seems necessary to evaluate the definition and categories of aquatic and semi-aquatic habits in these lizards through quantitative studies of locomotory performance.

A related issue is that since the seminal work of Pellegrino et al. (2001), attempts to infer Gymnophthalmidae evolutionary history mostly relay on the same four markers used in this study (approximately 2,000 aligned bp). This amount of data seems insufficient to satisfactorily resolve a radiation of nearly 300 species, which is illustrated by the low support values of most internal nodes and the conflicting topologies among different studies (e.g., Goicoechea et al. 2012, 2016; Pyron et al. 2013; Kok 2015; Torres-Carvajal et al. 2015, 2016; this study). We suggest that studies addressing Gymnophthalmidae systematics and evolution would strongly benefit from an increase in character sampling.

Lizards with a semi-aquatic and secretive mode of life are very difficult to locate and collect, and most times finding them is a matter of luck. Therefore, securing samples requires large sampling efforts. Although only a few herpetological surveys had been carried out in the Cuao-Sipapo massif and surrounding areas (Gorzula \& Señaris 1999; Barrio-Amorós et al. 2004; Rojas-Runjaic et al. 2013), this locality is only $~ 62 \mathrm{~km}$ from Puerto Ayacucho-the capital of the Venezuelan Amazonas state-, which in comparison to the Cuao-Sipapo massif has been extensively explored by naturalists. The fact that only one specimen of Kataphraktosaurus ungerhamiltoni is known, suggests that this is a rather secretive and/or rare lizard, with a geographic distribution restricted to the Cuao-Sipapo massif. Given that the western Guiana Shield lowland herpetofauna is predominantly represented by widely distributed Guianan-Amazonian taxa (Rojas-Runjaic \& Señaris 2019; Señaris \& Rojas-Runjaic 2020), the absence of reports of this lizard from relatively well-sampled localities in the lowlands of western Guiana Shield leads us to suspect that its type locality is in the lower limit of its altitudinal range, which probably extends towards the uplands of the Cuao-Sipapo massif.

Limited sample sizes in systematics are a problematic reality (Castroviejo-Fisher et al. 2011; Lim et al. 2012). The description of a new species on the basis of one specimen, singletons (Lim et al. 2012), represents the most extreme example because variation cannot be taken into account. This challenging situation can be somehow overcome if variation of putative diagnostic characters is well-understood within the other comparative units, there is congruence among different datasets, the singleton is well-preserved so diagnostic characters are very unlikely to result from preservation artifacts, and the singleton type locality data is detailed and precise to allow potential future collections (Köhler \& Padial 2016; Guayasamin et al. 2018). Our description of Kataphraktosaurus ungerhamiltoni is supported by molecular and morphological characters, its type locality is described with accuracy, and the specimen is well-preserved. However, the knowledge of the variation of diagnostic characters within CLM gymnophthalmids is limited because several species are only known from a handful of specimens, such as Neusticurus tatei (Burt \& Burt, 1931) and Rheosaurus sulcarostrum. The solution is theoretically simple but complicated to execute: only an 
increase of character and specimen sampling can improve the situation. Despite this uncertainty regarding variation, we argue that explaining the data at hand as the product of other known mechanisms responsible for organism variation (e.g., development, sexual dimorphism, intraspecies variation, and preservation artifacts) would require further assumptions and complicated scenarios.

We suggest to categorize Kataphraktosaurus ungerhamiltoni as "Data Deficient" (DD) according to the IUCN Red List (2019) because it is only known from one locality and a single specimen, with no additional information about its ecology, population status, and potential threats. Although there is some tourist activity in the Tobogán del Cuao and surroundings, the forests of that region are well-preserved, and above $500 \mathrm{~m}$ asl they are protected by the "Macizo Cuao-Sipapo y Cerro Moriche" Natural Monument.

\section{Acknowledgements}

We thank Lourdes Alcaraz who carried out the molecular laboratory work, funded by project CGL2014-56160-P of the Spanish Government (PI: I. De la Riva). Lourdes Echevarría and Andrés Jaramillo assisted us with some computational analyses, Germán Chávez kindly provided us with a photo for figure 3, and Juan M. Daza provided early access to sequences of Echinosaura and Rheosaurus. We are also grateful to Germán Chávez, Juan D. VázquezRestrepo (reviewers), and Karin Tamar (Associate Editor) who helped us to improve a previous version of the manuscript with their constructive criticism. Finally, we are indebted to Isabel Parra for its hospitality and logistic support during our fieldtrip to Amazonas. Collection permits (\#4156 and \#5179) were issued to FJMRR through MHNLS, by the Venezuelan Ministerio del Poder Popular para el Ambiente. Financial support was provided by Conselho Nacional de Desenvolvimento Científico e Tecnológico, CNPq, Brazil (SCF, grant \#: 312744/ 2017-0), and the PrInt program of Coordenação de Aperfeiçoamento de Pessoal de Nivel Superior, CAPES, Brazil (SCF, grant \#: 88887.508359/2020-00).

\section{References}

Aguirre-Peñafiel, V., Torres-Carvajal, O., Nunes, P.M.S., Peck, M.R. \& Maddok, S.T. (2014) A new species of Riama Gray, 1858 (Squamata: Gymnophthalmidae) from the Tropical Andes. Zootaxa, 3866 (2), 246-260. https://doi.org/10.11646/zootaxa.3866.2.4

Altamirano-Benavides, M., Zaher, H., Lobo, L., Grazziotin, F.G., Nunes, P.M.S. \& Rodrigues, M.T. (2013) A new species of lizard genus Potamites from Ecuador (Squamata, Gymnophthalmidae). Zootaxa, 3717 (3), 345-358. https://doi.org/10.11646/zootaxa.3717.3.4

Arèvalo, E., Davis, S.K. \& Sites Jr., J.W. (1994) Mitochondrial DNA sequence divergence and phylogenetic relationships among eight chromosome races of the Sceloporus grammicus complex (Phrynosomatidae) in central Mexico. Systematic Biology, 43 (3), 387-418. https://doi.org/10.1093/sysbio/43.3.387

Barbour, T. (1924) Two noteworthy new lizards from Panama. Proceedings of the New England Zoological Club, 9, 7-10.

Barrio-Amorós, C.L., Fuentes, O. \& Rivas, G. (2004) Two new species of Colostethus (Anura: Dendrobatidae) from the Venezuelan Guayana. Salamandra, 40 (3-4), 183-200.

Boulenger, G.A. (1890) First report on additions to the lizard collection in the British Museum (Natural History). Proceedings of the Zoological Society of London, 1890, 77-86.

Boulenger, G.A. (1911) III.-Descriptions of new reptiles from the Andes of South America, preserved in the British Museum. Annals and Magazine of Natural History, 7, 19-25. https://doi.org/10.1080/00222931108692903

Burt, C.E. \& Burt, M.D. (1931) South American lizards in the collection of the American Museum of Natural History. Bulletin of the American Museum of Natural History, 61, 227-395.

Castoe, T.A., Doan, T.M. \& Parkinson, C.L. (2004) Data partitions and complex models in bayesian analysis: The phylogeny of gymnophthalmid lizards. Systematic Biology, 53 (3), 448-469. https://doi.org/10.1080/10635150490445797

Castroviejo-Fisher, S., Vilà, C., Ayarzagüena, J., Blanc, M. \& Ernst, R. (2011) Species diversity of Hyalinobatrachium glassfrogs (Amphibia: Centrolenidae) from the Guiana Shield, with the description of two new species. Zootaxa, 3132 (1), 1-55. https://doi.org/10.11646/zootaxa.3132.1.1

Doan, T.M. \& Castoe, T.A. (2003) Using morphological and molecular evidence to infer species boundaries within Proctoporus bolivianus Werner (Squamata: Gymnophthalmidae). Herpetologica, 59 (3), 432-449. https://doi.org/10.1655/03-09 
Doan, T.M. \& Castoe, T.A. (2005) Phylogenetic taxonomy of the Cercosaurini (Squamata: Gymnophthalmidae), with new genera for species of Neusticurus and Proctoporus. Zoological Journal of the Linnean Society, 143 (3), 405-416. https://doi.org/10.1111/j.1096-3642.2005.00145.x

Donnelly, M.A., MacCulloch, R.D., Ugarte, C.A. \& Kizirian, D. (2006) A new riparian gymnophthalmid (Squamata) from Guyana. Copeia, 2006 (3), 396-403. https://doi.org/10.1643/0045-8511(2006)2006[396:ANRGSF]2.0.CO;2

Edgar, R.C. (2004) MUSCLE: multiple sequence alignment with high accuracy and high throughput. Nucleic Acids Research, $32(5), 1792-1797$. https://doi.org/10.1093/nar/gkh340

Fang, J.M., Vásquez-Restrepo, J.D. \& Daza, J.M. (2020) Filling the gaps in a highly diverse Neotropical lizard lineage: a new and endemic genus of Cercosaurinae (Squamata: Gymnophthalmidae) with the description of two new species from the Northern Andes of Colombia. Systematics and Biodiversity, 18 (5), 417-433. https://doi.org/10.1080/14772000.2020.1783714

Fritts, T.H. \& Smith, H.M. (1969) A new teiid lizard genus from western Ecuador. Transactions of the Kansas Academy of Science, 72 (1), 54-59. https://doi.org/10.2307/3627048

Fritts, T.H., Almendariz, A. \& Samec, S. (2002) A new species of Echinosaura (Gymnophthalmidae) from Ecuador and Colombia with comments on other members of the genus and Teuchocercus keyi. Journal of Herpetology, 36 (3), 349-355. https://doi.org/10.1670/0022-1511(2002)036[0349:ANSOEG]2.0.CO;2

Fu, J. (2000) Toward the phylogeny of the family Lacertidae-Why 4708 base pairs of mtDNA sequences cannot draw the picture. Biological Journal of the Linnean Society, 71 (2), 203-217. https://doi.org/10.1111/j.1095-8312.2000.tb01254.x

Goicoechea, N., Padial, J.M., Chaparro, J.C., Castroviejo-Fisher, S. \& De la Riva, I. (2012) Molecular phylogenetics, species diversity, and biogeography of the Andean lizards of the genus Proctoporus (Squamata: Gymnophthalmidae). Molecular Phylogenetics and Evolution, 65 (3), 953-964. https://doi.org/10.1016/j.ympev.2012.08.017

Goicoechea, N., Frost, D.R., De la Riva, I., Pellegrino, K., Sites, J., Rodrigues, M.T. \& Padial, J.M. (2016) Molecular systematics of teioid lizards (Teioidea/Gymnophthalmoidea: Squamata) based on the analysis of 48 loci under tree-alignment and similarity-alignment. Cladistics, 32 (6), 624-671.

https://doi.org/10.1111/cla.12150

Gorzula, S. \& Señaris, J.C. (1999 [“1998”]) Contribution to the herpetofauna of the Venezuelan Guayana I. A data base. Scientia Guaianae, 8, 1-269.

Guayasamin, J.M., Arteaga, A. \& Hutter, C.R. (2018) A new (singleton) rainfrog of the Pristimantis myersi Group (Amphibia: Craugastoridae) from the northern Andes of Ecuador. Zootaxa, 4527 (3), 323-334. https://doi.org/10.11646/zootaxa.4527.3.2

ICZN (1999) International Code of Zoological Nomenclature. Fourth Edition. The International Trust for Zoological Nomenclature, London, $306 \mathrm{pp}$.

IUCN (2019) Guidelines for Using the IUCN Red List Categories and Criteria. Version 14. Prepared by the Standards and Petitions Committee. Available from: http://www.iucnredlist.org/documents/RedListGuidelines.pdf (accessed 20 October 2020)

Köhler, J. \& Padial, J.M. (2016) Description and phylogenetic position of a new (singleton) species of Oreobates Jiménez de la Espada, 1872 (Anura: Craugastoridae) from the Yungas of Cochabamba, Bolivia. Annals of Carnegie Museum, 84 (1), $23-38$. https://doi.org/10.2992/007.084.0104

Köhler, G., Bohme, W. \& Schmitz, A. (2004) A new species of Echinosaura (Squamata: Gymnophthalmidae) from Ecuador. Journal of Herpetology, 38 (1), 52-60. https://doi.org/10.1670/164-02A

Kok, P.J.R. (2015) A new species of the Pantepui endemic genus Riolama (Squamata: Gymnophthalmidae) from the summit of Murisipán-tepui, with the erection of a new gymnophthalmid subfamily. Zoological Journal of the Linnean Society, 174 (3), 500-518. https://doi.org/10.1111/zoj.12241

Kok, P.J.R., MacCulloch, R.D., Means, D.B., Roelants, K., Van Bocxlaer, I. \& Bossuyt, F. (2012) Low genetic diversity in tepui summit vertebrates. Current Biology, 22 (15), R589-R590. https://doi.org/10.1016/j.cub.2012.06.034

Kok, P.J.R., Bittenbinder, M.A., van den Berg, J.K., Marques-Souza, S., Nunes, P.M.S., Laking, A.E., Teixeira Jr., M., Fouquet, A., Means, D.B., MacCulloch, R.D. \& Rodrigues, M.T. (2018) Integrative taxonomy of the gymnophthalmid lizard Neusticurus rudis Boulenger, 1900 identifies a new species in the eastern Pantepui region, north-eastern South America. Journal of Natural History, 52 (13-16), 1029-1066. https://doi.org/10.1080/00222933.2018.1439541

Kumar, S., Stecher, G. \& Tamura, K. (2016) MEGA7: Molecular Evolutionary Genetics Analysis version 7.0 for bigger datasets. Molecular Biology and Evolution, 33 (7), 1870-1874. 
https://doi.org/10.1093/molbev/msw054

Lanfear, R., Frandsen, P.B., Wright, A.M., Senfeld, T. \& Calcott, B. (2017) PartitionFinder 2: new methods for selecting partitioned models of evolution for molecular and morphological phylogenetic analyses. Molecular Biology and Evolution, 34 (3), 772-773. https://doi.org/10.1093/molbev/msw260

Larsson, A. (2014). AliView: a fast and lightweight alignment viewer and editor for large data sets. Bioinformatics, 30 (22), 3276-3278. https://doi.org/10.1093/bioinformatics/btu531

Lehr, E., Moravec, J., Lundberg, M., Köhler, G., Catenazzi, A. \& Šmid, J. (2019) A new genus and species of arboreal lizard (Gymnophthalmidae: Cercosaurinae) from the eastern Andes of Peru. Salamandra, 55 (1), 1-13.

Lehr, E., Moravec, J. \& von May, R. (2020) A new cryptic genus of terrestrial lizard (Gymnophthalmidae: Cercosaurinae) from the eastern Andes of central Peru. Salamandra, 56 (1), 1-15.

Lim, G.S., Balke, M. \& Meier, R. (2012) Determining species boundaries in a world full of rarity: singletons, species delimitation methods. Systematic Biology, 61 (1), 165-169. https://doi.org/10.1093/sysbio/syr030

Lotzkat, S., Batista, A., Vargas, J., Hertz, A. \& Köhler, G. (2012) Reptilia, Squamata, Gymnophthalmidae, Potamites apodemus (Uzzell, 1966): Distribution extension and first records from Panama. Check List, 8 (2), 302-306. https://doi.org/10.15560/8.2.302

Mamani, L., Chaparro, J.C., Correa, C., Alarcón, C., Salas, C.Y. \& Catenazzi, A. (2020) A new species of Andean gymnophthalmid lizard (Squamata: Gymnophthalmidae) from the Peruvian Andes, and resolution of some taxonomic problems. Diversity, $12(9), 361$. https://doi.org/10.3390/d12090361

Marques-Souza, S., Prates, I., Fouquet, A., Camacho, A., Kok, P.J.R., Nunes, P.M.S., Dal Vechio, F., Recoder, R.S., Mejia, N., Junior, M.T., Barrio-Amorós, C., Cassimiro, J., Lima, J.D., de Sena, M.A. \& Rodrigues, M.T. (2018) Reconquering the water: evolution and systematics of South and Central American aquatic lizards (Gymnophthalmidae). Zoologica Scripta, 47 (3), 255-265.

https://doi.org/10.1111/zsc. 12273

Moravec, J., Šmíd, J., Štundl, J. \& Lehr, E. (2018) Systematics of Neotropical microteiid lizards (Gymnophthalmidae, Cercosaurinae), with the description of a new genus and species from the Andean montane forests. ZooKeys, 774, 105139. https://doi.org/10.3897/zookeys.774.25332

Miller, M.A., Pfeiffer, W. \& Schwartz, T. (2010) Creating the CIPRES Science Gateway for inference of large phylogenetic trees. In: 2010 Gateway Computing Environments Workshop (GCE). IEE, New Orleans, pp. 1-8. https://doi.org/10.1109/GCE.2010.5676129

Palumbi, S.R., Martin, A., Romano, S., McMillan, W.O., Stice, L. \& Grabowski, G. (1991) The simple fool's guide to PCR. Version 2.0. Department of Zoology and Kewalo Marine Laboratory, University of Hawaii, Honolulu, 45 pp.

Parra, V., Nunes, P.M.S. \& Torres-Carvajal, O. (2020) Systematics of Pholidobolus lizards (Squamata, Gymnophthalmidae) from southern Ecuador, with descriptions of four new species. ZooKeys, 954, 109-156. https://doi.org/10.3897/zookeys.954.50667

Pellegrino, K.C.M., Rodrigues, M.T., Yonenaga-Yassuda, Y. \& Sites Jr, J.W. (2001) A molecular perspective on the evolution of microteiid lizards (Squamata, Gymnophthalmidae), and a new classification for the family. Biological Journal of Linnean Society, 74 (3), 315-338. https://doi.org/10.1006/bij1.2001.0580

Pellegrino, K.C.M., Brunes, T.O., Souza, S.M., Laguna, M.M., Avila-Pires, T.C.S., Hoogmoed, M.S. \& Rodrigues, M.T. (2018) On the distinctiveness of Amapasaurus, its relationship with Loxopholis Cope, 1869, and description of a new genus for $L$. guianensis and L. hoogmoedi (Gymnophthalmoidea/Ecpleopodini: Squamata). Zootaxa, 4441 (2), 332-346. https://doi.org/10.11646/zootaxa.4441.2.8

Pyron, R.A., Burbrink, F.T. \& Wiens, J.J. (2013) A phylogeny and revised classification of Squamata, including 4161 species of lizards and snakes. BMC Evolutionary Biology, 13 (93), 1-53. https://doi.org/10.1186/1471-2148-13-93

Recoder, R.S., Dal Vechio, F., Marques-Souza, S., Teixeira Jr., M., Silva-Da-Silva, M., Santos-Jr., A.P., Ribeiro, S., BarrioAmorós, C. \& Rodrigues, M.T. (2018) Geographic variation and taxonomy of red-tailed Gymnophthalmus (Squamata: Gymnophthalmidae) from Amazonian savannas. Zootaxa, 4497 (1), 061-081.

https://doi.org/10.11646/zootaxa.4497.1.4

Recoder, R., Prates, I., Marques-Souza, S., Camacho, A., Nunes, P.M.S., Dal Vechio, F., Ghellere, J.M., McDiarmid, R.W. \& Rodrigues, M.T. (2020) Lizards from the Lost World: two new species and evolutionary relationships of the Pantepui highland Riolama (Gymnophthalmidae). Zoological Journal of the Linnean Society, 190 (1), 271-297. https://doi.org/10.1093/zoolinnean/zlz168

Rojas-Runjaic, F.J.M. \& Señaris, J.C. (2018) Reptiles del Escudo Guayanés de Venezuela. In: Lasso, C.A. \& Señaris, J.C. (Eds.), Fauna Silvestre del Escudo Guayanés (Colombia-Venezuela). Volumen VI. Serie Editorial Fauna Silvestre Neotropical. Instituto de Investigación de Recursos Biológicos Alexander von Humboldt, Bogotá, D.C., pp. 179-229. 
Rojas-Runjaic, F.J.M., Castroviejo-Fisher, S. \& Barrio-Amorós, C.L. (2013) First record of the Amazonian tiny tree toad Amazophrynella minuta (Melin, 1941) (Anura: Bufonidae), for Venezuela. Check List, 9 (5), 1122-1123. https://doi.org/10.15560/9.5.1122

Ruibal, R. (1952) Revisionary studies of some South American Teiidae. Bulletin of the Museum of Comparative Zoology, 106 (11), 477-529.

Saint, K.M., Austin, C.C., Donnellan, S.C. \& Hutchinson, M.N. (1998) C-mos, a nuclear marker useful for squamate phylogenetic analysis. Molecular Phylogenetics and Evolution, 10 (2), 259-263. https://doi.org/10.1006/mpev.1998.0515

Sánchez-Pacheco, S.J., Torres-Carvajal, O., Aguirre-Peñafiel, V., Nunes, P.M.S., Verrastro, L., Rivas, G.A., Rodrigues, M.T., Grant, T. \& Murphy, R.W. (2018) Phylogeny of Riama (Squamata: Gymnophthalmidae), impact of phenotypic evidence on molecular datasets, and the origin of the Sierra Nevada de Santa Marta endemic fauna. Cladistics, 34 (3), $260-291$. https://doi.org/10.1111/cla.12203

Señaris, J.C. \& Rojas-Runjaic, F.J.M. (2020) Amphibians and reptiles of Venezuelan Guayana: diversity, biogeography and conservation. In: Rull, V. \& Carnaval, A. (Eds.), Neotropical diversification: Patterns and Processes. Fascinating Life Sciences. Springer, Cham, pp. 571-633. https://doi.org/10.1007/978-3-030-31167-4_22

Sukumaran, J. \& Holder, M.T. (2010) DendroPy: a Python library for phylogenetic computing. Bioinformatics, 26 (12), 1569 1571. https://doi.org/10.1093/bioinformatics/btq228

Sukumaran, J. \& Holder, M.T. (2017) SumTrees: Phylogenetic Tree Summarization. 4.3.0. Available from: http://github.com/ jeetsukumaran/DendroPy (accessed 26 March 2020)

Teixeira Jr, M., Dal Vechio, F., Nunes, P.M.S., Neto, A.M., Lobo, L.M., Storti, L.F., Gaiga, R.A.J., Dias, P.H.F. \& Rodrigues, M.T. (2013) A new species of Bachia Gray, 1845 (Squamata: Gymnophthalmidae) from the western Brazilian Amazonia. Zootaxa, 3636 (3), 401-420. http://doi.org/10.11646/zootaxa.3636.3.1

Torres-Carvajal, O. \& Lobos, S.E. (2014) A new species of Alopoglossus lizard (Squamata, Gymnophthalmidae) from the tropical Andes, with a molecular phylogeny of the genus. ZooKeys, 410, 105-120. https://doi.org/10.3897/zookeys.410.7401

Torres-Carvajal, O. \& Mafla-Endara, P. (2013) Evolutionary history of Andean Pholidobolus and Macropholidus (Squamata: Gymnophthalmidae) lizards. Molecular Phylogenetics and Evolution, 68 (2), 212-217. https://doi.org/10.1016/j.ympev.2013.03.013

Torres-Carvajal, O., Lobos, S.E. \& Venegas, P.J. (2015) Phylogeny of Neotropical Cercosaura (Squamata: Gymnophthalmidae) lizards. Molecular Phylogenetics and Evolution, 93, 281-288. https://doi.org/10.1016/j.ympev.2015.07.025

Torres-Carvajal, O., Lobos, S.E., Venegas, P.J., Chávez, G., Aguirre-Peñafiel, V., Zurita, D. \& Echevarría, L.Y. (2016) Phylogeny and biogeography of the most diverse clade of South American gymnophthalmid lizards (Squamata, Gymnophthalmidae, Cercosaurinae). Molecular Phylogenetics and Evolution, 99, 63-75. https://doi.org/10.1016/j.ympev.2016.03.006

Torres-Carvajal, O., Venegas, P.J. \& Sales-Nunes, P.M. (2020) Description and phylogeny of a new species of Andean lizard (Gymnophthalmidae: Cercosaurinae) from the Huancabamba depression. South American Journal of Herpetology, 18 (1), 13-23. https://doi.org/10.2994/SAJH-D-18-00069.1

Uetz, P., Freed, P. \& Hošek, J. (2020) The Reptile Database. Available from: http://www.reptile-database.org (accessed 20 August 2020)

Uzzell, T.M. (1965) Teiid lizards of the genus Echinosaura. Copeia, 1965 (1), 82-89. https://doi.org/10.2307/1441244

Uzzell, T. (1966) Teiid lizards of the genus Neusticurus (Reptila, Sauria). Bulletin of the American Museum of Natural History, $132,277-328$.

Vaidya, G., Lohman, D.J. \& Meier, R. (2011) SequenceMatrix: concatenation software for the fast assembly of multigene datasets with character set and codon information. Cladistics, 27 (2), 171-180. https://doi.org/10.1111/j.1096-0031.2010.00329.x

Vásquez-Restrepo, J.D., Ibáñez, R., Sánchez-Pacheco, S.J. \& Daza, J.M. (2020) Phylogeny, taxonomy and distribution of the Neotropical lizard genus Echinosaura (Squamata: Gymnophthalmidae), with the recognition of two new genera in Cercosaurinae. Zoological Journal of the Linnean Society, 189 (1), 287-314. https://doi.org/10.1093/zoolinnean/zlz124

Wenzel, J.W. \& Carpenter, J.M. (1994) Comparing methods: adaptive traits and tests of adaptation. In: Eggleton, P. \& VaneWright, R.I. (Eds.), Phylogenetics and Ecology. Academic Press, London, pp. 79-101.

Zwickl, D.J. (2006) Genetic algorithm approaches for the phylogenetic analysis of large biological sequence datasets under the maximum likelihood criterion. Ph.D. dissertation, The University of Texas at Austin, University of Texas libraries, Austin, Texas, $115 \mathrm{pp}$. 


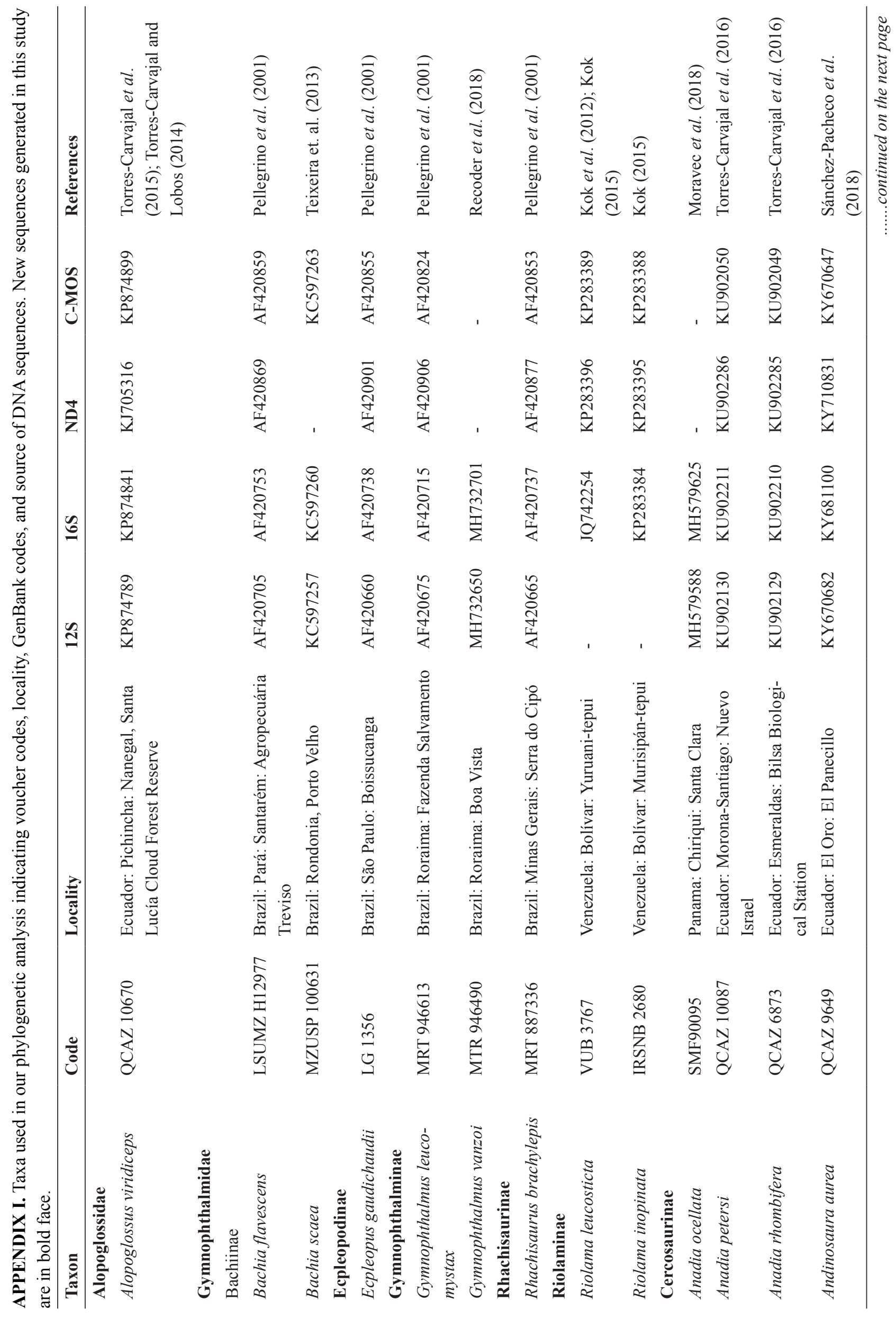




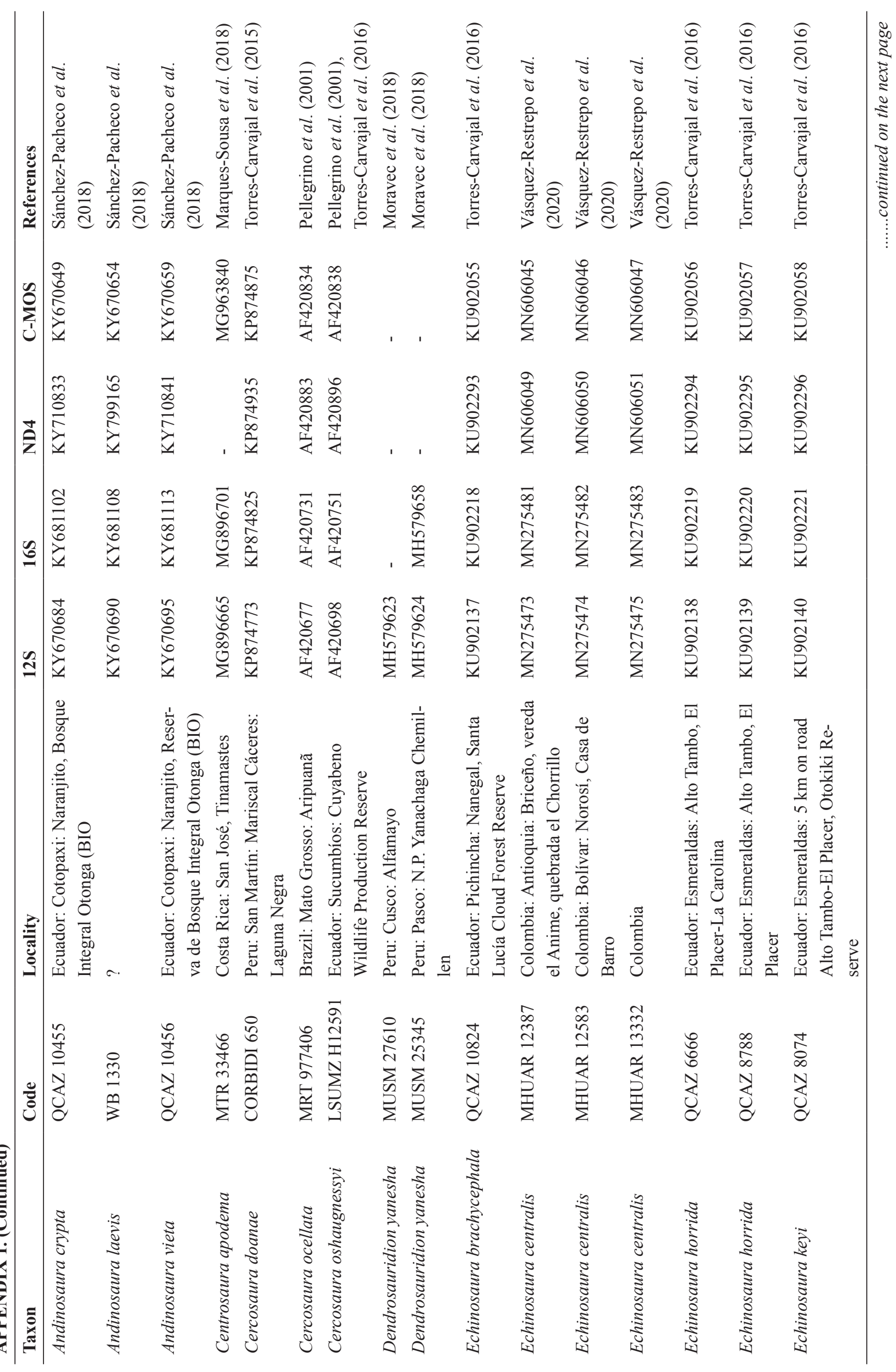




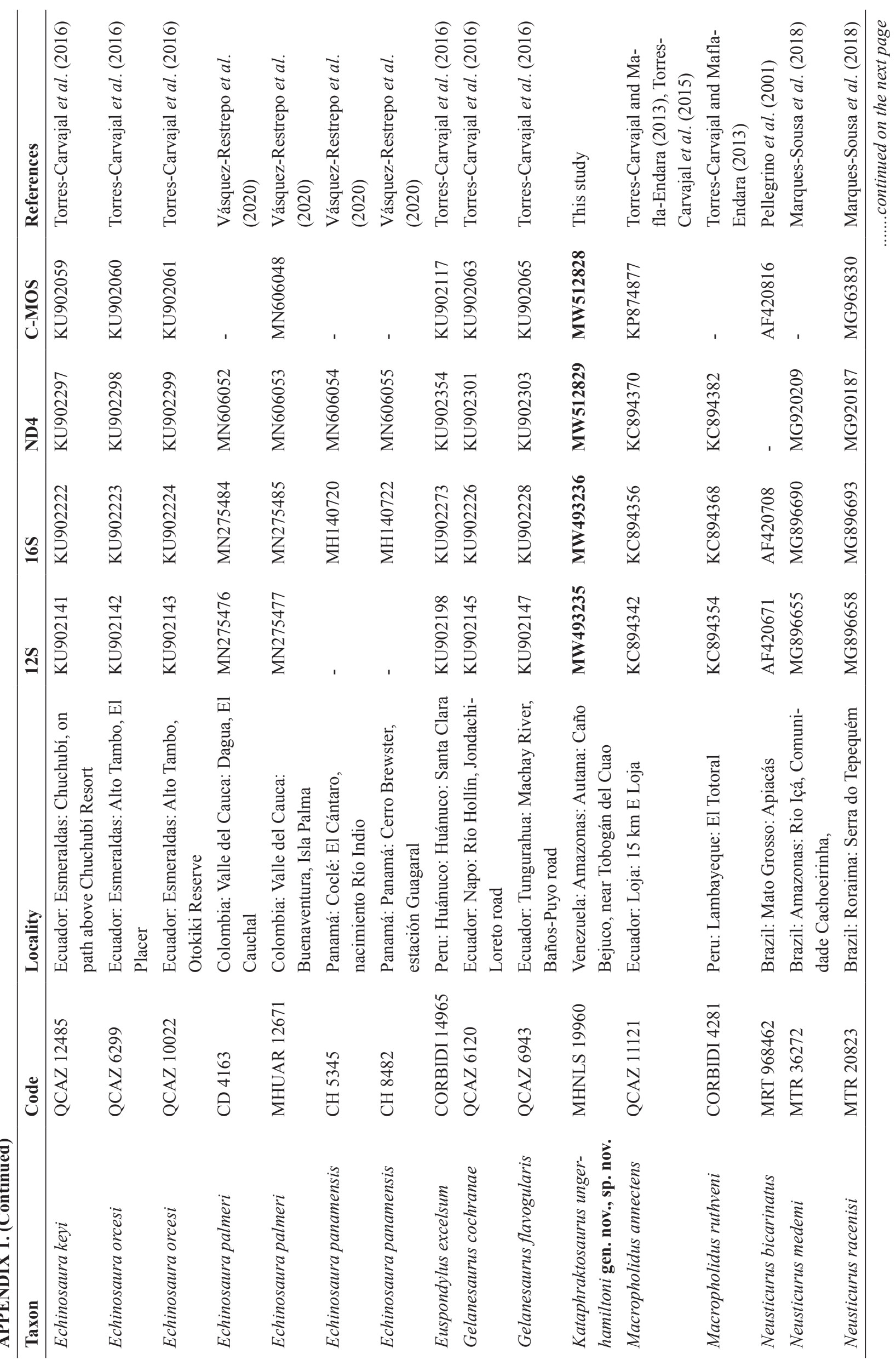




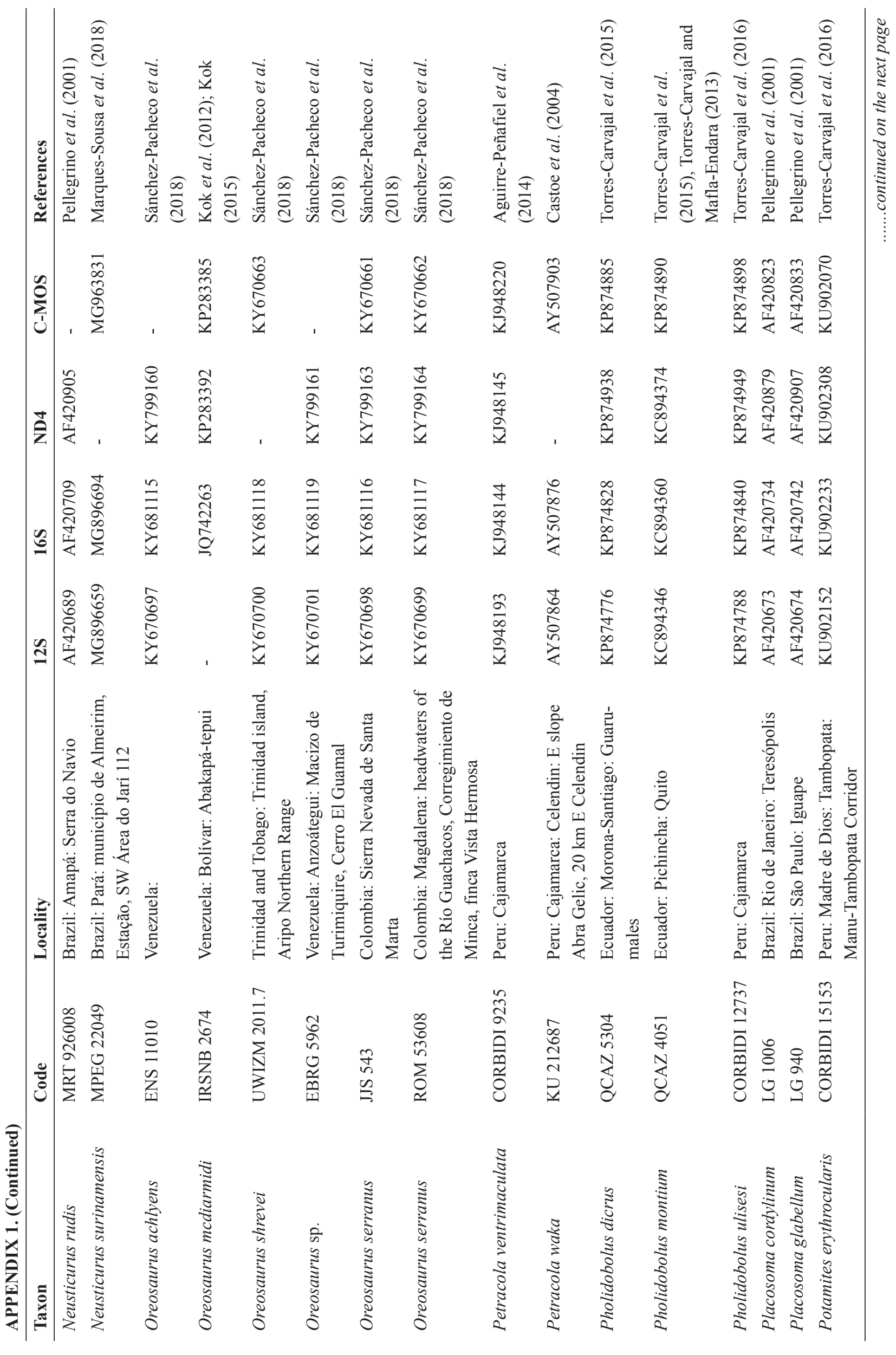




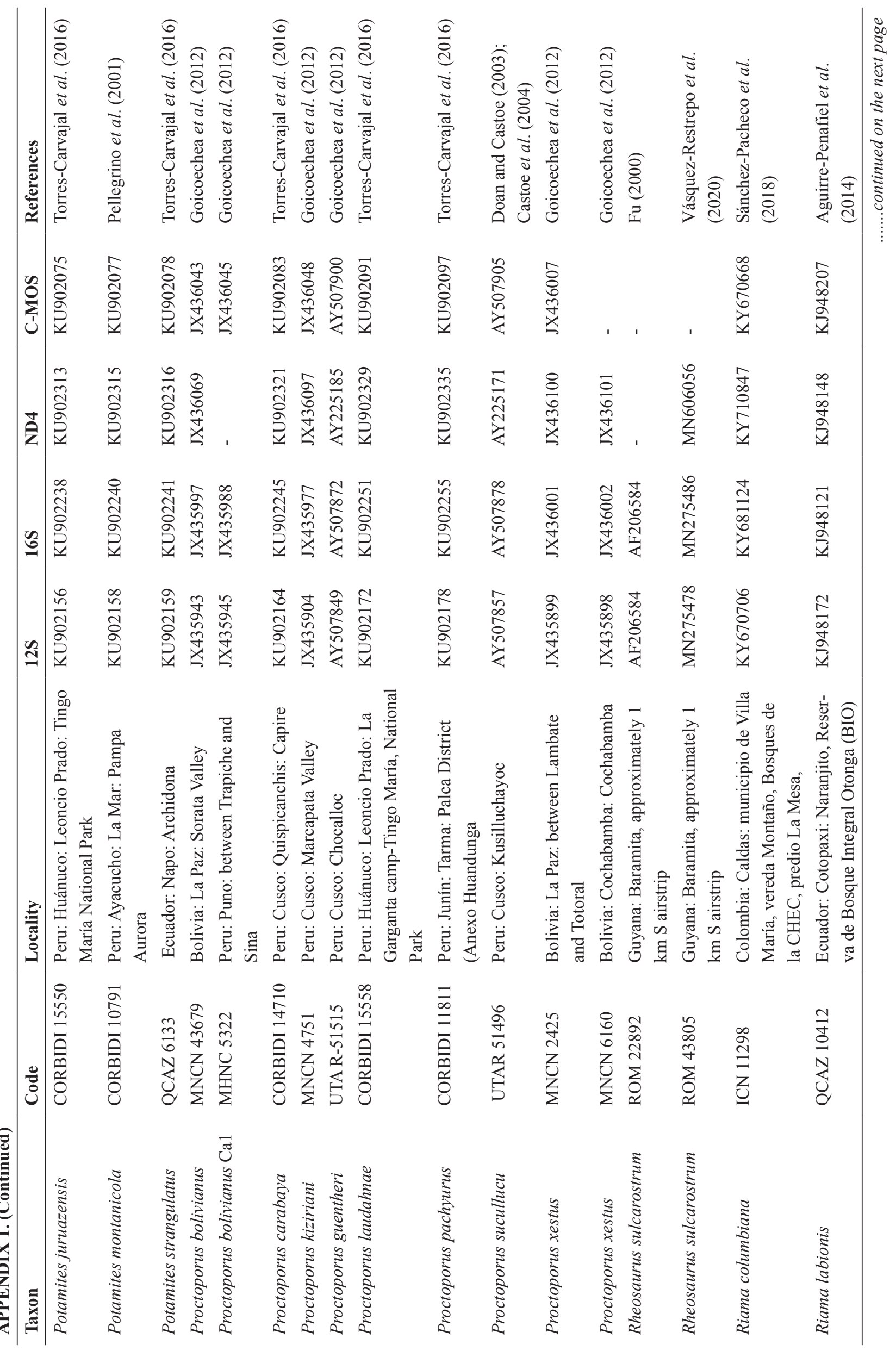




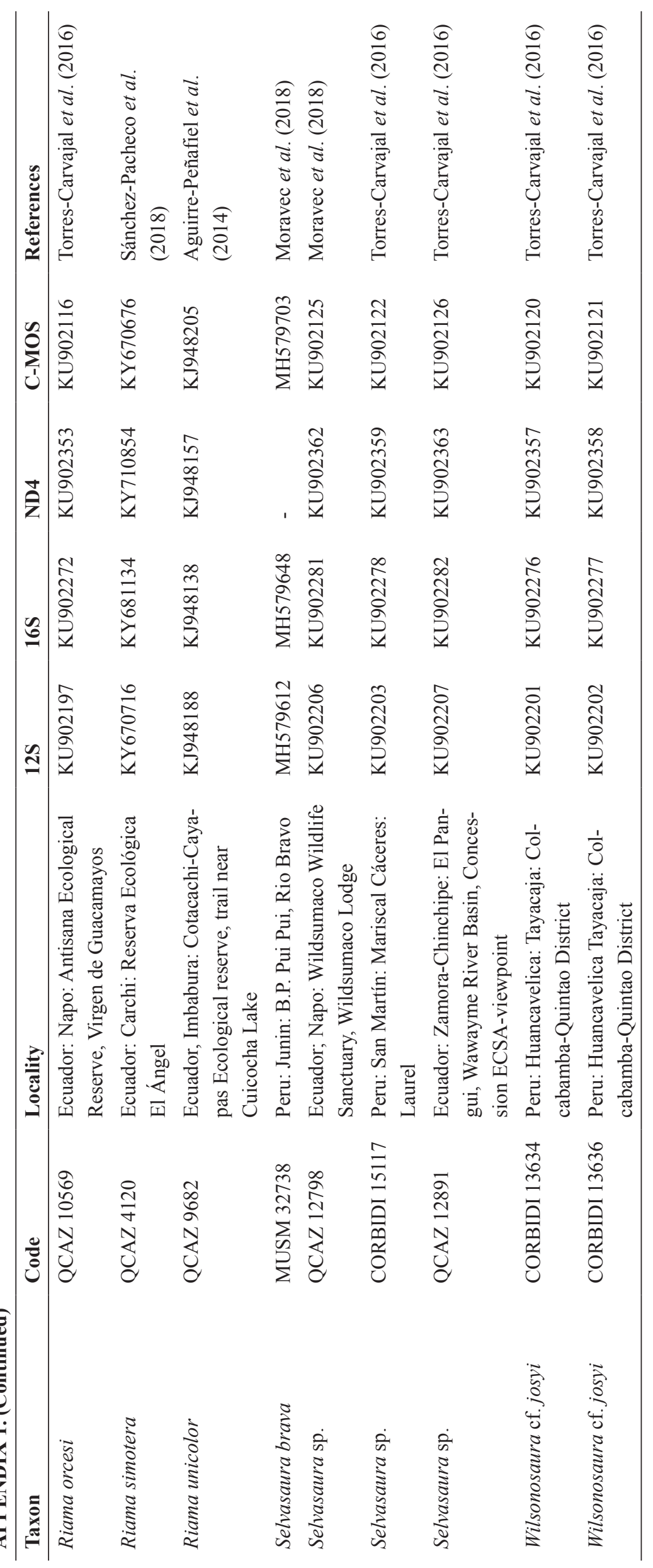

